Research paper

\title{
Comparison of high temperature chars of wheat straw and rice husk with respect to chemistry, morphology and reactivity
}

\author{
Anna Trubetskaya a, ", Peter Arendt Jensen a , Anker Degn Jensen a, Markus Steibel b, \\ Hartmut Spliethoff ${ }^{\mathrm{b}}$, Peter Glarborg ${ }^{\mathrm{a}}$, Flemming Hofmann Larsen ${ }^{\mathrm{c}, * *}$ \\ a Department of Chemical and Biochemical Engineering, Denmark Technical University, Søltofts Plads Bygning 229, Kgs. Lyngby 2800, Denmark \\ ${ }^{\mathrm{b}}$ Department of Mechanical Engineering, Institute for Energy Systems, Munich University of Technology, Boltzmannstrasse 15, Garching, Germany \\ ${ }^{c}$ Department of Food Science, Spectroscopy and Chemometrics, University of Copenhagen, Rolighedsvej 26, 1958 Copenhagen, Denmark
}

\section{A R T I C L E I N F O}

\section{Article history:}

Received 17 September 2015

Received in revised form

23 January 2016

Accepted 23 January 2016

Available online 2 February 2016

\section{Keywords:}

Fast pyrolysis

${ }^{29} \mathrm{Si}$ solid-state NMR

Entrained flow reactor

Oxygen reactivity

Si bearing compounds

\begin{abstract}
A B S T R A C T
Fast pyrolysis of wheat straw and rice husk was carried out in an entrained flow reactor at hightemperatures $(1000-1500){ }^{\circ} \mathrm{C}$. The collected char was analyzed using X-ray diffractometry, $\mathrm{N}_{2}$-adsorption, scanning electron microscopy, particle size analysis with CAMSIZER XT, ${ }^{29} \mathrm{Si}$ and ${ }^{13} \mathrm{C}$ solid-state nuclear magnetic resonance spectroscopy and thermogravimetric analysis to investigate the effect of inorganic matter on the char morphology and oxygen reactivity. The silicon compounds were dispersed throughout the turbostratic structure of rice husk char in an amorphous phase with a low melting temperature $\left(\approx 730^{\circ} \mathrm{C}\right)$, which led to the formation of a glassy char shell, resulting in a preserved particle size and shape of chars. The high alkali content in the wheat straw resulted in higher char reactivity, whereas the lower silicon content caused variations in the char shape from cylindrical to near-spherical char particles. The reactivities of pinewood and rice husk chars were similar with respect to oxidation, indicating less influence of silicon oxides on the char reactivity.
\end{abstract}

() 2016 Elsevier Ltd. All rights reserved.

\section{Introduction}

The use of combustion units entirely based on renewable energy is an important step in the reduction of greenhouse gas emissions. However, the chemical and physical properties of biomass are different from those of coal and vary significantly between wood and herbaceous species. This introduces a range of major technical challenges, related to the operation of the power plants. Irregular fibrous biomass particles increase the required energy input into the milling compared to coal, affecting the biomass burnout and creating additional challenges with the flame stability $[1,2]$.

The biomass utilization at Danish power plants focuses on wood pellets, but introduction of new solid biomass materials such as waste products from agriculture and energy crops, will demand an increased operational flexibility. The quality of agricultural wastes is lower than that of wood due to a higher ash content that leads to deposition and corrosion of the boiler units. Moreover, in pulverized biomass combustion only a short residence time is available for

\footnotetext{
* Corresponding author.

** Corresponding author

E-mail addresses: atru@kt.dtu.dk (A. Trubetskaya), fhl@food.ku.dk (F.H. Larsen).
}

biomass conversion, and the lignocellulosic material reactivity is affected by the biomass composition, namely organic matter and minerals [3-5].

Little is known about the structural transformation of pulverized biomass during high heating rate and high temperature pyrolysis. The majority of investigations on the biomass potential of agricultural waste is focused on wheat straw and rice husk chars, pyrolyzed under slow heating rate $\left(1-50 \mathrm{~K} \mathrm{~min}^{-1}\right)$ and long holding time $(1-4 \mathrm{~h})[6-11]$. The rice husk contains high concentrations of silicon that is present as silicon oxides with small amounts of alkalis and other trace elements. Lanning [12] concluded that silicon occurs in rice husk in a hydrated amorphous form (opal or silica gel), located mainly in the outer epidermis and filling the inner channels in the spiral structure of the epidermal cells. In addition, Liu et al. [13] and Sharma et al. [14] proposed that the silica in the rice husk is combined with carbohydrates. This hypothesis was examined and verified by ${ }^{29} \mathrm{Si}$ NMR by Freitas et al. [9]. Guerrero et al. [15] reported no major morphological changes of rice husk under fast heating, and ascribed this observation to a high thermal resistance of rice husk ash, containing mostly silicon compounds. Pottmaier et al. [11] concluded that rice husk is less reactive than wheat straw, 
prepared at temperatures $\left(300-1300{ }^{\circ} \mathrm{C}\right.$ ) under slow and fast heating, and related differences in reactivity to the higher contents of lignin and silicon in the rice husk. The investigation of Freitas et al. [9] on slowly pyrolyzed rice husk at high temperatures $\left(1000-1400{ }^{\circ} \mathrm{C}\right)$ and long holding time $(1-2 \mathrm{~h})$ indicated an increased formation of crystalline silicon carbides at the expense of amorphous silicon oxides with increasing temperature. Nehdi et al. [16] stated that silicon oxides in rice husk can remain in amorphous form at combustion temperatures of up to $900{ }^{\circ} \mathrm{C}$ if the combustion time is less than one hour, whereas crystalline silicon oxides are produced at $1000{ }^{\circ} \mathrm{C}$ with combustion time greater than $5 \mathrm{~min}$.

Several different methods have been used to characterize silicates from biomass pyrolysis and combustion. Nair et al. [17] showed that ${ }^{1} \mathrm{H}-{ }^{29} \mathrm{Si} \mathrm{CP} / \mathrm{MAS}$ solid-state NMR spectroscopy is more accurate than X-ray diffraction for the detection and quantification of the amorphous and crystalline Si bearing compounds. Hamdan et al. [18] studied rice husk ash, oxidized above $700^{\circ} \mathrm{C}$, and observed a broad $Q^{4}$ resonance without any silanol groups. The $Q^{n}$ notation refers to the number of bridging oxygens on a particular tetrahedral silicon site [19]. Abreu and Schneider [20] analyzed by rice husk oxidation in a fluidized bed furnace at temperatures up to $890{ }^{\circ} \mathrm{C}$ and observed the presence of $\mathrm{Q}^{3}$ and $\mathrm{Q}^{2}$ sites in the amorphous fraction and a small amount of crystalline material assigned to cristobalite. Bardet et al. [10] pointed out that the origin of biomass does not affect the char structure under slow heating at temperatures up to $700{ }^{\circ} \mathrm{C}$ due to the transformation of lignocellulosic materials (wood, fescue, wheat straw) to larger saturated polyaromatic domains [21], and the remaining inorganic matter is not intercalated inside the polycyclic structures.

The present work was focused on the fast pyrolysis of rice husk and wheat straw at high temperatures $\left(1000-1500{ }^{\circ} \mathrm{C}\right)$ performed in an entrained flow reactor at heating rates up to $10^{4} \mathrm{~K} \mathrm{~s}^{-1}$ to study the properties of chars derived from herbaceous biomass. The structural transformations of rice husk and wheat straw chars were characterized by $\mathrm{N}_{2}$-adsorption, X-ray diffraction (XRD), scanning electron microscopy (SEM), ${ }^{13} \mathrm{C}$ and ${ }^{29} \mathrm{Si}$ solid-state nuclear magnetic resonance spectroscopy (NMR). The reactivity and burnout of herbaceous chars were studied using a thermogravimetric (TG) analyzer.

\section{Materials and methods}

\subsection{Raw samples}

For this study, wheat straw and rice husk were selected, based on the large difference in ash composition together with a similar distribution among the three major biomass constituents (cellulose, hemicellulose, lignin) as it is shown by the compositional analysis in Table 1 . The rice husk contains a larger fraction of $\mathrm{Si}$ (9.8 wt.\% of the dry material) and significantly less alkali in comparison to wheat straw, which is rich in alkali (K: $1.1 \mathrm{wt} . \%$ of the dry material; Ca: 0.24 wt.\% of the dry material) but contains substantially lower Si (0.84 wt.\% of the dry material). The raw rice husk (Oryza sativa L.) and wheat straw (Triticum aestivum L.) originate from North Vietnam (Sapa plantage) and Denmark (Aabenraa plantage). The rice husk and wheat straw were dried at $30{ }^{\circ} \mathrm{C}$ for several days in an oven desiccator without any ventilation. The moisture content decreased from 12 to 15 wt.\% (as received biomass) to less than 5 wt.\% (dry basis biomass) which ensured continuous biomass feeding in the entrained flow reactor.

Prior to the pyrolysis experiments, both rice husk and wheat straw were comminuted on a hammer mill (Andritz manufacturer) with an operating speed of $60 \mathrm{~Hz}$. The wheat straw stems (20-40 $\mathrm{mm}$ ) with leaves were grinded in two steps on a hammer mill down to $1 \mathrm{~mm}$ and thereafter down to $0.15 \mathrm{~mm}$. In addition,
Table 1

Proximate, ultimate and compositional analyses of lignocellulosic materials. The abbreviations ar, db, wt stay for as received, dry basis and weight percentage. The proximate, ultimate and compositional analyses were conducted on wheat straw and rice husk particles sieved to $0.09-0.18 \mathrm{~mm}$.

\begin{tabular}{|c|c|c|}
\hline Fuel & Wheat straw & Rice husk \\
\hline \multicolumn{3}{|l|}{ Proximate analysis } \\
\hline Moisture, (wt.\% ar) & 5.5 & 4.5 \\
\hline $\operatorname{Ash}\left(550^{\circ} \mathrm{C}\right),(\mathrm{wt} . \% \mathrm{db})$ & 4.1 & 21.7 \\
\hline Volatiles, (wt.\% db) & 77.5 & 64.3 \\
\hline $\mathrm{HHV},\left(\mathrm{MJ} \mathrm{kg}^{-1}\right)$ & 18.8 & 15.5 \\
\hline $\mathrm{LHV},\left(\mathrm{MJ} \mathrm{kg}^{-1}\right)$ & 17.5 & 14.5 \\
\hline \multicolumn{3}{|c|}{ Ultimate analysis, (wt.\% db) } \\
\hline $\mathrm{C}$ & 46.6 & 37.8 \\
\hline $\mathrm{H}$ & 6.1 & 4.7 \\
\hline $\mathrm{N}$ & 0.6 & 0.3 \\
\hline 0 & 42.5 & 35.5 \\
\hline $\mathrm{S}$ & 0.1 & 0.03 \\
\hline $\mathrm{Cl}$ & 0.1 & 0.05 \\
\hline \multicolumn{3}{|c|}{ Ash compositional analysis, $\left(\mathrm{mg} \mathrm{kg}^{-1} \mathrm{db}\right)$} \\
\hline $\mathrm{Al}$ & 150 & 70 \\
\hline $\mathrm{Ca}$ & 2500 & 750 \\
\hline $\mathrm{Fe}$ & 200 & 80 \\
\hline $\mathrm{K}$ & 11,000 & 2500 \\
\hline $\mathrm{Mg}$ & 750 & 400 \\
\hline $\mathrm{Na}$ & 150 & 70 \\
\hline $\mathrm{P}$ & 500 & 600 \\
\hline $\mathrm{Si}$ & 8500 & 98,500 \\
\hline $\mathrm{Ti}$ & 10 & 5 \\
\hline \multicolumn{3}{|c|}{ Structural analysis of biomass, (wt.\% db) } \\
\hline Cellulose & 35.9 & 36.7 \\
\hline Hemicellulose & 18 & 17.7 \\
\hline Lignin (acid insoluble) & 19.2 & 21.6 \\
\hline Lignin (acid soluble) & 6.5 & 1.2 \\
\hline Extractives & 10.1 & 1 \\
\hline Protein & 6.3 & 0.6 \\
\hline
\end{tabular}

wheat straw and rice husk were sieved to a particle size fraction of 0.09-0.18 $\mathrm{mm}$ to exclude particles with a characteristic length exceeding $0.5 \mathrm{~mm}$, which could create challenges during the biomass feeding in the entrained flow reactor.

The compositional analysis of the biomass (cellulose, hemicellulose, acid-soluble lignin, acid-insoluble lignin, protein and extractives) was conducted according to NREL technical reports [22-24] and Thammasouk et al. [25]. The water-ethanol extraction was performed on wheat straw and rice husk which contained a high level of hydrophilic and lipophilic extractable compounds, according to the procedure described in the Supplemental material [25].

This work was performed on substrates of unknown provenance, for which the chain of custody is not known. The species cultivars cannot be specified, while the authors believe that this work exemplifies the difference between wheat straw and rice husk - there is a reasonable concern that there may be substrate factors that influence the results obtained if the work was performed with different cultivars, grown under different conditions.

\subsection{Experimental procedure}

\subsubsection{Entrained flow reactor}

The entrained flow study was carried out with the Baby High Temperature Entrained Flow Reactor (BabiTER) at TU Munich. The layout of the reactor is shown in Fig. 1 [26,27]. The BabiTER can be operated at atmospheric pressure and at a maximal temperature of $1600{ }^{\circ} \mathrm{C}$. The particle residence time for the investigation in this work is below $1 \mathrm{~s}$, calculated from the average gas residence time, and considering the effects of particle free fall velocity, velocity profile and biomass particle properties.

A defined gas mixture (2) is preheated (4) before entering the 


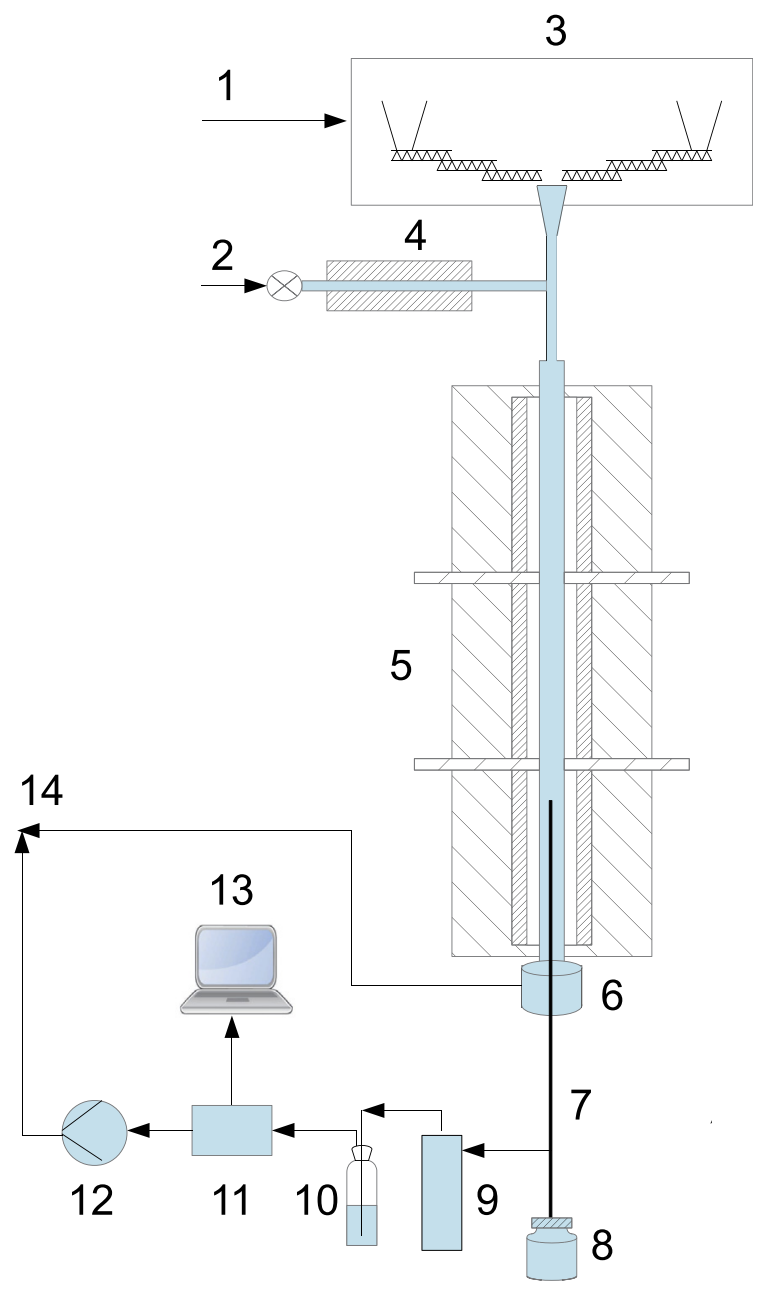

Fig. 1. Schematic view of the entrained flow reactor (BabiTER) at TU Munich [26,27]: 1 . Feeding gas $\left(\mathrm{N}_{2}\right) ; 2$. Main gas $\left(\mathrm{N}_{2}\right) ; 3$. Fuel feeding system; 4. Pre-heater; 5. Tube furnace; 6 . Water quench; 7. Collection probe; 8 . Solid residue char bin; 9 . Metal filter; 10. Impinger bottle; 11. Gas analyzer; 12. Pump (Venturi); 13. Gas analysis/measurement controller; 14. Exhaust gas.

reaction tube (40 $\mathrm{mm}$ inner diameter, $1400 \mathrm{~mm}$ length, 99.7\% $\mathrm{Al}_{2} \mathrm{O}_{3}$ ). The reaction tube (5) is surrounded by three heating zones, each consisting of four $\mathrm{MoSi}_{2}$ heating elements. A feeding system (3) is enclosed in a container and purged with nitrogen of $99.999 \%$ high purity (1) to prevent air entering the reactor. It consists of two independently acting dosing systems which are placed on opposite sides. Each feeding system contains three vibrational chutes and one batch weighting unit for a constant and uniform transport of the biomass materials into the reactor.

The mass flow of the pulverized biomass can be varied from $50 \mathrm{~g} \mathrm{~h}^{-1}$ to $1 \mathrm{~kg} \mathrm{~h}^{-1}$ and is controlled by a software connected to the balances. The pre-heated nitrogen is mixed with the biomass in the entry of the reaction tube. Char and gas samples in the reaction zone can be collected by a water cooled sampling probe (7), which is adjustable in height. The gas flow rate, sucked by the sampling probe, can be varied by a venturi nozzle, such that iso-kinetic sampling can be performed. Particles and gases, which are not collected with the sampling probe, are quenched by water (6). The collected char in the sampling probe is separated from the reaction gas on a char filter (9), and collected in a char bin (8). A part of the reaction gas is analyzed using a non-dispersive infrared analysis (NDIR)/heat conductivity analyzer (13) for process control. In this work, the experiments were carried out with the entrained flow reactor at temperatures of 1000,1250 and $1500{ }^{\circ} \mathrm{C}$. The BabiTER system is limited to use particles with a characteristic length $<0.5 \mathrm{~mm}$. A biomass feeding rate of $300 \mathrm{~g} \mathrm{~h}^{-1}$ was selected for the rice husk. At 1000 and $1250{ }^{\circ} \mathrm{C}$, the wheat straw was fed with $200 \mathrm{~g} \mathrm{~h}^{-1}$, and at $1500{ }^{\circ} \mathrm{C}$ with $100 \mathrm{~g} \mathrm{~h}^{-1}$ to ensure continuous biomass feeding. The sampling probe was kept at a constant height, enabling a residence time of about $1 \mathrm{~s}$ during all experiments.

\subsubsection{Char characterization}

\subsubsection{SEM microscopy}

SEM/EDS analysis of char was conducted on a microscope (FEI Company, Inspect) with a tungsten filament under high vacuum in order to understand char structural and chemical properties. Prior to the analysis, char samples were coated with a thin layer of carbon (40 s, $5 \mathrm{~mA}$ ) using a Cressington 208 Carbon Coater to avoid sample charging. SEM/EDS analysis in a backscattered electron mode was carried out as an average composition of 20 points on rice husk char particles and wheat straw tar balls, generated at $1500{ }^{\circ} \mathrm{C}$

\subsubsection{CAMSIZER XT}

The particle size and shape of the original biomass and its char were measured on a 2D imaging instrument (CAMSIZER XT, Retsch), designed for the particle size range of $3 \mu \mathrm{m}-3 \mathrm{~mm}$. Particle shadows were captured by two cameras, namely a zoom camera, designed for the analysis of smaller particles, and a basic-camera that was able to detect larger particles. The projected area of the particles was analyzed by the CAMSIZER XT 6.3.10 software. Fine biomass particles tend to agglomerate which makes it difficult to detect the true geometric dimensions of each individual particle. Therefore, the particle agglomerates were separated without destroying the primary particles by air pressure dispersion. The particle size distribution, based on the volume, is represented by the $\mathrm{x}_{\mathrm{Ma} \text {,min }}$ diameter. For the particle size analysis, ca. $100 \mathrm{mg}$ of a sample was used. All measurements were conducted in triplicate to establish sufficient reproducibility within $<0.5 \%$.

The Martin minimal $\left(\mathrm{x}_{M a, \min }\right)$ and Feret maximal $\left(\mathrm{x}_{F e, \max }\right) \mathrm{di}-$ ameters are suitable parameters to represent the biomass particle width and length in combustion. The Martin diameter is a chord length that divides the projected particle area into two equal halves [28] as shown in Supplementary Fig. S-5.1. The minimal Martin diameter $\left(\mathrm{x}_{\mathrm{Ma} \text {,min }}\right)$ is determined from the smallest Martin diameter of the particle projection [29], and represents a particle width based on the assumption of a biomass particle to be thinner than its width in the diffusion process of a combustion modeling. The Feret diameter is a distance between two tangents placed perpendicular to the measurement direction [28] as shown in Supplementary Fig. S-5.2. The Feret maximal diameter is the longest Feret diameter of all measured Feret diameters of a particle [29], and the longest measurable diameter $\mathrm{x}_{\mathrm{Fe} \text {,max }}$ is the largest diameter to fulfill the assumption that the length of a particle has to be larger than its width. The results of a particle size analysis were represented as a frequency distribution over $\mathrm{x}_{\mathrm{Ma} \text {,min }}$, based on volume.

The particle shape is characterized by sphericity (SPHT) and aspect ratio $\left(\mathrm{b} \mathrm{l}^{-1}\right.$ ) in the present study. Sphericity is one of the most common ways to express the deviation of an 2D image shape from a sphere and is defined by Equation (1):

SPHT $=\frac{4 * \pi * A}{P^{2}}$

In Equation (1), $\mathrm{P}$ is a measured circumference of a particle projection and $A$ is a measured area of a particle projection. The particle is considered to be spherical when the value of sphericity is equal to 1 and non-spherical when it is less than 1 . The aspect ratio 
AR is defined as the ratio of particle width $\left(\mathrm{b}=\mathrm{x}_{\text {Mamin }}\right)$ to the particle length $\left(1=\mathrm{x}_{\mathrm{Fe} \text {,max }}\right)$.

$A R=\frac{b}{l}$

\subsubsection{X-ray diffraction}

The crystalline constituents of the pulverized chars, generated at $1000-1500{ }^{\circ} \mathrm{C}$, were characterized using a Huber G670 X-ray diffractometer with a copper tube (CuK $\alpha 1$ radiation, $\lambda=1.54056 \AA$ ) from a quartz monochromator, using an imaging strip covering $100^{\circ}$ as a detector for $1.5 \mathrm{~h}$. The diffractometer was operated in a transmission mode with the sample placed in a thin layer into a flat disc-like rotating sample holder. The collected XRD patterns were analyzed using Crystallographica Search-Match software (Version $3,1,0,0)$. The XRD peak broadening was subtracted from the experimental pattern by the Winprep software (DTU Chemistry).

\subsubsection{Ash compositional analysis}

The ash compositional analysis was performed by an X-ray fluorescence instrument (Shimadzu, model EDX 800-HS) at TU Munich. Prior to the XRF analysis, char samples were pre-heated in oxygen at $5 \mathrm{~K} \mathrm{~min}^{-1}$ up to $550{ }^{\circ} \mathrm{C}$ and kept at that temperature for $7 \mathrm{~h}$. The generated ash (about $200 \mathrm{mg}$ ) was initially mixed and then pressed with a special wax (mixture ratio 1:5). The $\mathrm{Cl}$ and $\mathrm{S}$ content in the ash was analyzed by ICP-OES/IC at TU Wien. The ash sample was dissolved in ultrapure water at $120^{\circ} \mathrm{C}$ for $1 \mathrm{~h}$, and then the solution was filtered and analyzed by ICP-OES/IC.

\subsubsection{5. ${ }^{13} \mathrm{C}$ and ${ }^{29} \mathrm{Si}$ solid state NMR spectroscopy}

Solid-state NMR analysis was carried out on a Bruker Avance 400 NMR spectrometer $(9.4 \mathrm{~T})$ operating at Larmor frequencies of $400.13,100.58$ and $79.48 \mathrm{MHz}$ for ${ }^{1} \mathrm{H},{ }^{13} \mathrm{C}$ and ${ }^{29} \mathrm{Si}$, respectively. All experiments were conducted using a double resonance probe equipped with $4 \mathrm{~mm}$ (o.d.) rotors. Samples were analyzed as without any additional preparation at room temperature by singlepulse (SP) magic angle spinning (MAS) as well as cross polarization (CP) MAS [30] utilizing high-power ${ }^{1} \mathrm{H}$ two-pulse phase-modulated decoupling (TPPM) [31] during acquisition and employing a spinning rate of $9 \mathrm{kHz}$. The ${ }^{13} \mathrm{C} \mathrm{CP} /$ MAS spectra were recorded using a recycle delay of $8 \mathrm{~s}$, a contact time of $1 \mathrm{~ms}$, an acquisition time of $45.9 \mathrm{~ms}$ and 4096 scans, whereas the ${ }^{13} \mathrm{C}$ SP/MAS spectra were recorded using a recycle delay of $128 \mathrm{~s}$, an acquisition time of $45.9 \mathrm{~ms}$ and 1080 scans. The ${ }^{29} \mathrm{Si} \mathrm{CP} / \mathrm{MAS}$ spectra were recorded using a recycle delay of $2 \mathrm{~s}$, a contact time of $8 \mathrm{~ms}$, an acquisition time of $42.6 \mathrm{~ms}$ and 8192 scans, while a recycle delay of $256 \mathrm{~s}$, an acquisition time of $42.6 \mathrm{~ms}$ and 512 scans were utilized for recording the ${ }^{29} \mathrm{Si} \mathrm{SP} / \mathrm{MAS}$ spectra. All recycle delays and contact times were optimized on the original biomass of wheat $\operatorname{straw}\left({ }^{13} \mathrm{C}\right)$ and protobind $1000\left({ }^{29} \mathrm{Si}\right)$ and then used for all samples in this study. The NMR spectra were referenced to TMS (0 ppm) using secondary reference compounds. All ${ }^{13} \mathrm{C}$ NMR spectra were referenced to the carbonyl resonance in an external sample of $\alpha$-glycine at $176.5 \mathrm{ppm}$ [32], and the ${ }^{29} \mathrm{Si}$ NMR spectra were referenced to an external sample of 3-(Trimethylsilyl)-1-propanesulfonic acid sodium salt at $1.6 \mathrm{ppm}$.

\subsubsection{6. $\mathrm{N}_{2}$-adsorption analysis}

The specific surface area (SSA) of biomass chars was determined based on nitrogen adsorption at its boiling point ( $77 \mathrm{~K}$ ). To remove surface contaminants, the samples were heated to $350{ }^{\circ} \mathrm{C}$ in a dry $\mathrm{N}_{2}$ flow prior to the measurement. The multipoint Brunauer-Emmett-Teller (BET) theory with seven points in the range of $\mathrm{p} / \mathrm{p}_{0}$ from 0.01 to 0.2 is applied on the BET instrument (Quantachrome iO2). BET equation was used to determine the specific surface area [33].

\subsubsection{Thermogravimetric analysis}

The reactivity of char was determined using a TG instrument (Netzsch, STA $449 \mathrm{~F} 1$ ) by loading $3 \mathrm{mg}$ of sample in an $\mathrm{Al}_{2} \mathrm{O}_{3}$ crucible and heating it from 35 to $1350{ }^{\circ} \mathrm{C}$ in $5 \%$ volume fraction $\mathrm{O}_{2}$ $\left(50 \mathrm{~cm}^{3} \mathrm{~min}^{-1}\right.$ of $\mathrm{O}_{2}$ and $95 \mathrm{~cm}^{3} \mathrm{~min}^{-1}$ of $\mathrm{N}_{2}$ ) measured at $20^{\circ} \mathrm{C}$ and $101.3 \mathrm{kPa}$ and at a constant heating rate of $10 \mathrm{~K} \mathrm{~min}^{-1}$.

The kinetic parameters of char samples were derived by the integral method presented by Coats and Redfern [34]. Through integral transformation and mathematical approximation, the linear equation was expressed in the form:

$\ln \left(-\frac{\ln (1-X)}{T^{2}}\right)=\ln \left(\frac{A \cdot R}{\beta \cdot E_{a}}\right)-\frac{E_{a}}{R \cdot T}$

where $\beta$ is the heating rate and $R$ is the gas constant. A plot of $\ln \left(-\ln (1-X) \mathrm{T}^{-2}\right)$ versus $\mathrm{T}^{-1}$ gives a straight line whose slope and intercept determine the values of the activation energy $\left(E_{a}\right)$ and pre-exponential factor (A). The results of Qin et al. [35] showed that a first order reaction model in both char mass and gasification agent can describe the experimental results well. The reactivities of wheat straw and rice husk chars were compared using reaction rates calculated for the derived kinetic parameters $\left(A\right.$ and $\left.E_{a}\right)$ at a fixed oxidation temperature of $400{ }^{\circ} \mathrm{C}$.

\section{Results and discussion}

\subsection{Ash analysis}

The ash composition of the original rice husk and its chars was analyzed by X-ray fluorescence (XRF), Inductively Coupled Plasma Optical Emission Spectroscopy (ICP-OES) and Ion Chromatography (IC) and shown in Fig. 2. The chars were collected from the fast pyrolysis at 1000,1250 and $1500^{\circ} \mathrm{C}$, and the analysis showed a high concentration of silicon oxides along with smaller amounts of potassium, aluminium, iron, sodium and magnesium. The wheat straw char at all applied heat treatment temperatures contained potassium and calcium along with a high concentration of silicon, leading to the formation of silicates [36]. Fig. 2 shows that close to $70 \%$ potassium in the wheat straw has been released in a

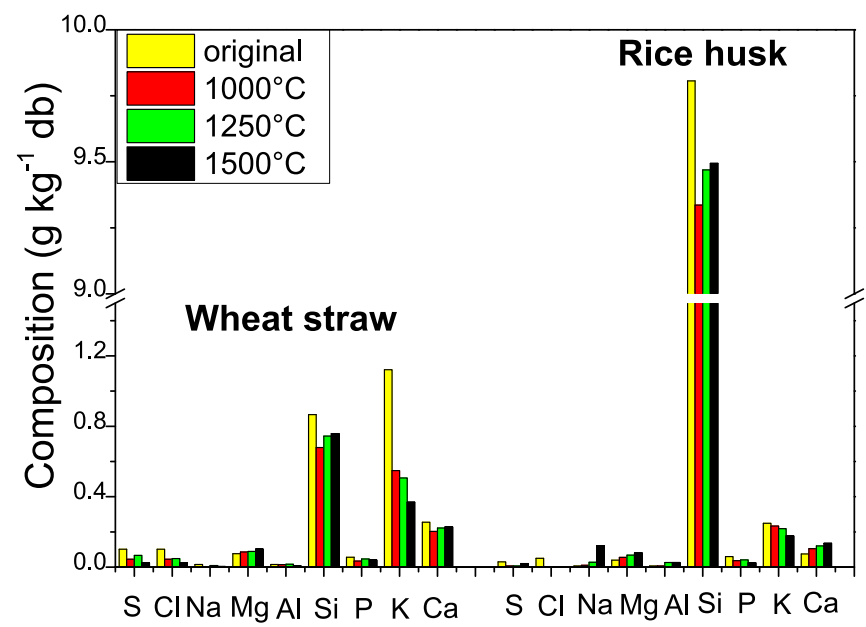

Fig. 2. Ash compositional analysis of rice husk and wheat straw, pyrolyzed in the BabiTER reactor at 1000,1250 and $1500{ }^{\circ} \mathrm{C}$. The ash composition of both lignocellulosic materials and their chars is shown in $\mathrm{g} \mathrm{kg}^{-1}$ on dry basis. 
temperature range of $1000-1500{ }^{\circ} \mathrm{C}$, and the residual potassium at $1500{ }^{\circ} \mathrm{C}$ retained in the silicate matrix. Equilibrium calculations were conducted for the major inorganic components in the wheat straw (K, Si and Ca) as shown in Supplementary Table S-2 using the Factsage software. These calculations indicated that potassium silicates $\left(\mathrm{K}_{2} \mathrm{SiO}_{3}\right.$ and $\mathrm{K}_{2} \mathrm{Si}_{2} \mathrm{O}_{5}$, melting temperature $<900{ }^{\circ} \mathrm{C}$ [37] $)$ and calcium silicate $\left(\mathrm{Ca}_{3} \mathrm{Si}_{2} \mathrm{O}_{7}\right.$, melting temperature $<1450{ }^{\circ} \mathrm{C}$ [38]) should be present in the wheat straw chars.

\subsection{X-ray diffraction}

The structural characteristics of the biomass chars, formed during the fast pyrolysis in the BabiTER reactor, have been examined by X-ray diffraction (XRD) in terms of carbon and ash transformations. The X-ray diffractograms for the wheat straw and rice husk chars, prepared at $1000-1500{ }^{\circ} \mathrm{C}$, are shown in Fig. 3. In the original rice husk, silicon oxides are present in an amorphous form

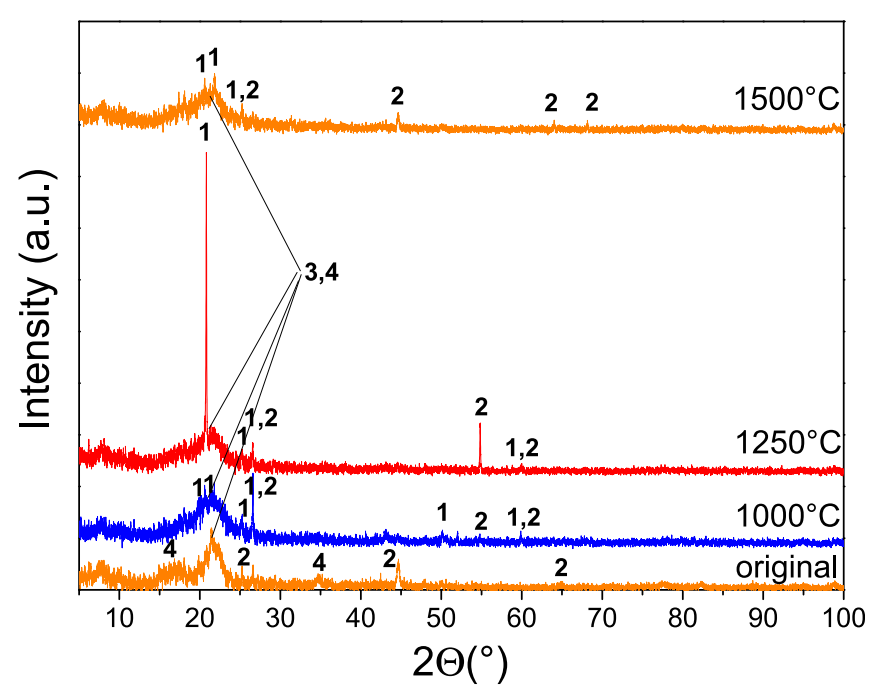

(a): Rice husk

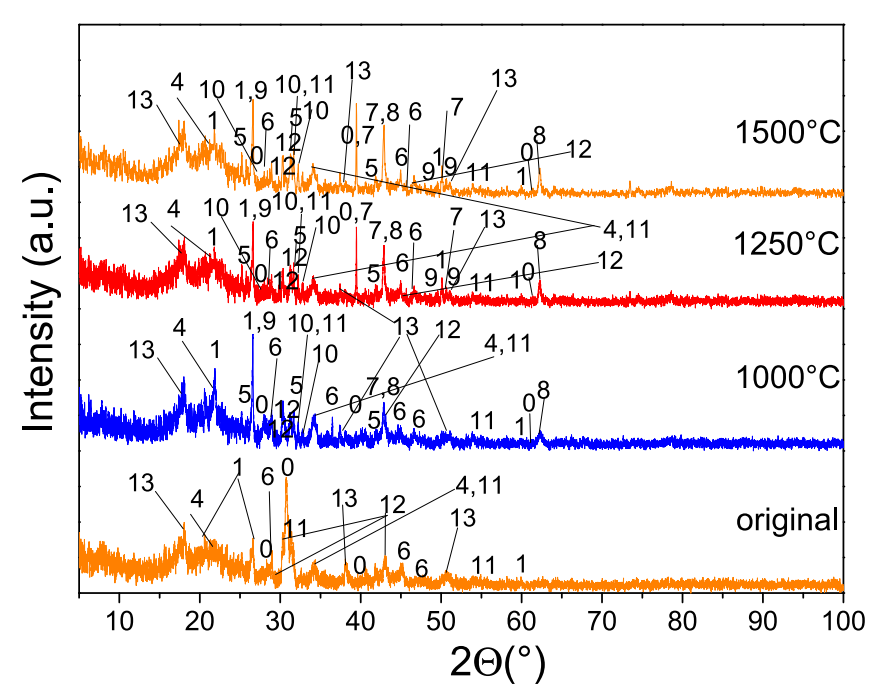

(b): Wheat straw

Fig. 3. XRD measurements of original wheat straw and rice husk and chars. The XRD patterns were assigned to: $0-\mathrm{KCl}, 1-\mathrm{SiO}_{2}$ (tridymite, cristobalite, quartz), $2-$ Mullite, 3 - Amorphous silica, 4 - Turbostratic structure, $5-\mathrm{K}_{2} \mathrm{CO}_{3}, 6-\mathrm{CaCO}_{3}, 7-$ $\mathrm{CaSO}_{4}, 8-\mathrm{MgO}, 9-\mathrm{Ca}_{3}\left(\mathrm{PO}_{4}\right)_{2}, 10-\mathrm{KOH}, 11-\mathrm{CaO}, 12-\mathrm{K}_{2} \mathrm{SO}_{4}, 13-\mathrm{Ca}(\mathrm{OH})_{2}[70]$. bonded with monosaccharides [8], corresponding to the diffuse peak with its maximum at about $2 \Theta=21.8^{\circ}$. The XRD peak at $21.8^{\circ}$, measured for the original rice husk, remained at the same position for the chars with increasing heat treatment temperature in the present study.

The weak sharp and narrow reflections from crystalline silicon oxides as compared to the broad band of amorphous silicon oxides $\left(2 \Theta=21.8^{\circ}\right)$ indicate only partial crystallization at high heating conditions. Comparing the reflections from crystalline silicates in the rice husk ash oxidized for $24 \mathrm{~h}$ reported by Hamdan et al. [18] and in glass-ceramics investigated by Jing et al. [39], the reflections from crystalline silicates in the rice husk chars are significantly weaker in the present study. The XRD results indicate that the rice husk chars exhibit mainly amorphous silicates structure with a few weak reflections from crystalline silicates. The XRD analysis did not show any $\mathrm{SiC}$ peaks between 1000 and $1500^{\circ} \mathrm{C}$ as it was previously observed under slow heating and at heat treatment temperatures below $1000{ }^{\circ} \mathrm{C}$ by Sharma et al. [40].

In comparison to the rice husk, the XRD analysis of wheat straw char between 1000 and $1500{ }^{\circ} \mathrm{C}$ showed a wide range of inorganic components, mostly present as oxides $\left(\mathrm{SiO}_{2}, \mathrm{CaO}, \mathrm{MgO}\right)$ as illustrated in Fig. 3(b). In addition to the oxides, potassium and calcium elements form carbonates and sulfates. The potassium retained in the ash was proposed to appear as hydroxide [2] and to a minor extent as chloride due to the low concentration of chlorine [41]. With the exception of $\mathrm{Ca}_{3}\left(\mathrm{PO}_{4}\right)_{2}$ and $\mathrm{CaSO}_{4}$ identified here, all other compounds identified in this study have been previously detected in ash samples by $\mathrm{Wu}$ et al. [2]. The peaks at about $23^{\circ}, 34.4^{\circ}$ and $42.5^{\circ}$ in the wheat straw char indicated a decrease in cellulose crystallinity and formation of a turbostratic structure [42-44]. The peak at $23^{\circ}$ in the rice husk char was hypothesized to overlap with the broad peak of amorphous silicon oxides at $21.8^{\circ}$.

\section{3. ${ }^{13} \mathrm{C}$ NMR and ${ }^{29} \mathrm{Si} N \mathrm{NMR}$}

The effect of heat treatment temperature on the organic matter transformation in the rice husk and wheat straw fast pyrolysis was monitored using ${ }^{13} \mathrm{C} \mathrm{CP} / \mathrm{MAS}$ and ${ }^{13} \mathrm{C} \mathrm{SP} / \mathrm{MAS}$ NMR spectroscopy. In the ${ }^{13} \mathrm{C} \mathrm{CP} / \mathrm{MAS}$ experiments the resonances of the carbons in immobile regions of the samples were enhanced by polarization transfer from the highly abundant ${ }^{1} \mathrm{H}$ nuclei via hetero-nuclear dipolar coupling. All carbon sites were observed quantitatively by the ${ }^{13} \mathrm{C}$ SP/MAS NMR measurements. In Figs. 4 and 5, the ${ }^{13} \mathrm{C} \mathrm{CP} /$ MAS and ${ }^{13} \mathrm{C} \mathrm{SP} / \mathrm{MAS} N M R$ spectra of rice husk and wheat straw and chars produced at different heat treatment temperatures are displayed, and an assignment of resonances is shown in Supplementary Table S-3 using literature data [45-49].

Comparing the spectra of the original biomass to the spectra of the chars at $1000{ }^{\circ} \mathrm{C}$ showed that the polysaccharides were the most abundant components in the original biomass, whereas the spectra of chars are characterized by a broad resonance centered at $125 \mathrm{ppm}$ originating from aromatics. Above $1000{ }^{\circ} \mathrm{C}$ it was observed that no resonances were present in the $\mathrm{CP} / \mathrm{MAS}$ spectra and that the S/N-ratio in the SP/MAS spectra were reduced. These spectra indicate the aromatization of the lignocellulosic material and formation of graphene-like structures [9]. The reasons for the lack of resonances in the $\mathrm{CP} / \mathrm{MAS}$ spectra of the pyrolyzed samples are the lower content of hydrogen as shown in Supplementary Table S-1 and a higher content of paramagnetic species (e.g. radicals) in the sample.

$\mathrm{SP} / \mathrm{MAS}$ and $\mathrm{CP} / \mathrm{MAS}$ spectra were also recorded, but the ${ }^{29} \mathrm{Si} \mathrm{CP} /$ MAS only resulted in observable resonances for the original biomass, which is in agreement with the results of Freitas et al. [9]. The higher heat treatment temperatures led to the low hydrogen content of chars which made unlikely occurrence of silanol groups 


\section{${ }^{13} \mathrm{C}$ CP/MAS NMR}

$1500^{\circ} \mathrm{C}$

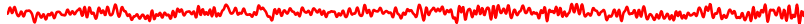

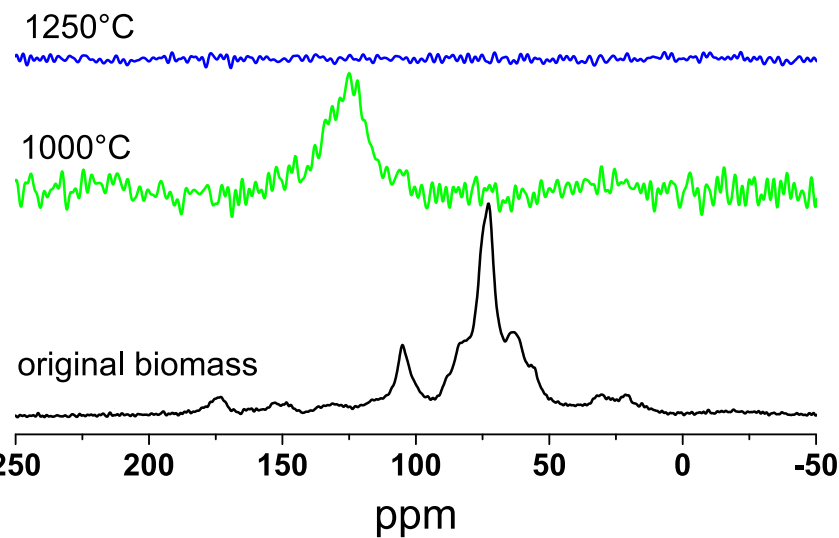

(a): Rice husk ${ }^{13} \mathrm{C} \mathrm{CP} / \mathrm{MAS}$ NMR

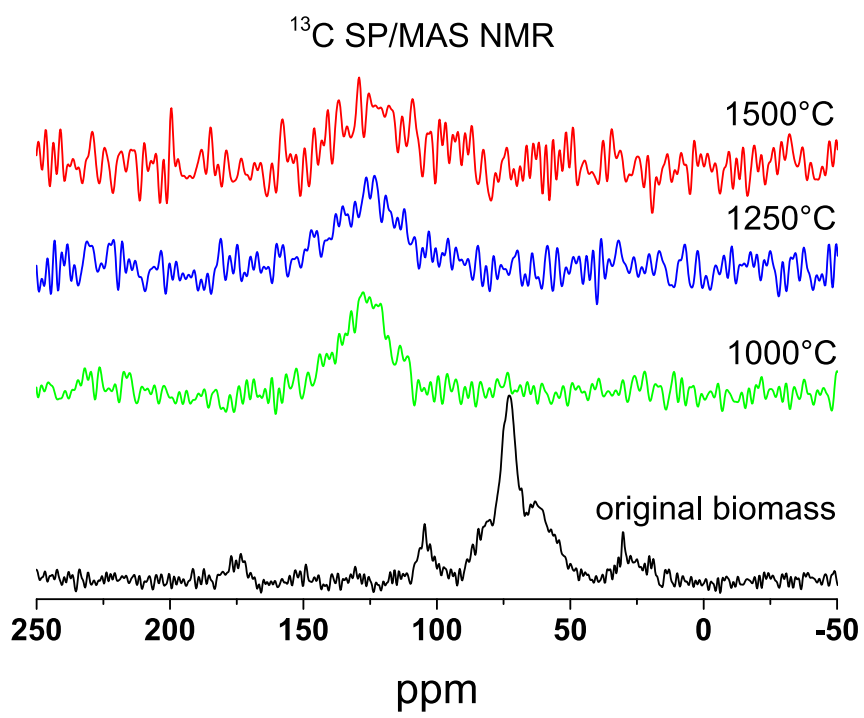

(b): Rice husk ${ }^{13} \mathrm{C} \mathrm{SP} / \mathrm{MAS}$ NMR

Fig. 4. ${ }^{13} \mathrm{C} \mathrm{CP} / \mathrm{MAS}$ and ${ }^{13} \mathrm{C} \mathrm{SP} / \mathrm{MAS}$ spectra of rice husk and its chars generated at 1000 1250 and $1500{ }^{\circ} \mathrm{C}$.

at fast pyrolysis conditions. In Fig. 6, the spectra of rice husk chars, prepared at $1000-1500{ }^{\circ} \mathrm{C}$ in the entrained flow reactor are presented. By comparison of the SP/MAS and the CP/MAS spectra of the original biomass the $\mathrm{Si}$ sites situated close to hydrogen are identified as these are enhanced by $\mathrm{CP}$. Another factor influencing $\mathrm{CP} /$ MAS spectra is related to the presence of paramagnetic species which reduce the efficiency of the polarization transfer, leading to no resonances present in the $\mathrm{CP} / \mathrm{MAS}$ spectra of chars generated at 1250 and $1500{ }^{\circ} \mathrm{C}$. The resonances in the SP/MAS spectra can be characterized by a broad intense resonance at $-111 \mathrm{ppm}$ assigned to $\mathrm{Q}^{4}$ sites and less intense shoulders at $-102 \mathrm{ppm}$ and at $-92 \mathrm{ppm}$ assigned to the $Q^{3}$ and $Q^{2}$ sites, respectively, as shown in Fig. 6 $[17,50]$. In Table 2 , the mean chemical shift and line width are displayed.

Deconvolution of the spectra by Gaussian functions (leastsquares fitting of spectra) resulted in Gaussian curves from which the full width at half maximum was obtained as shown in Fig. 7. A

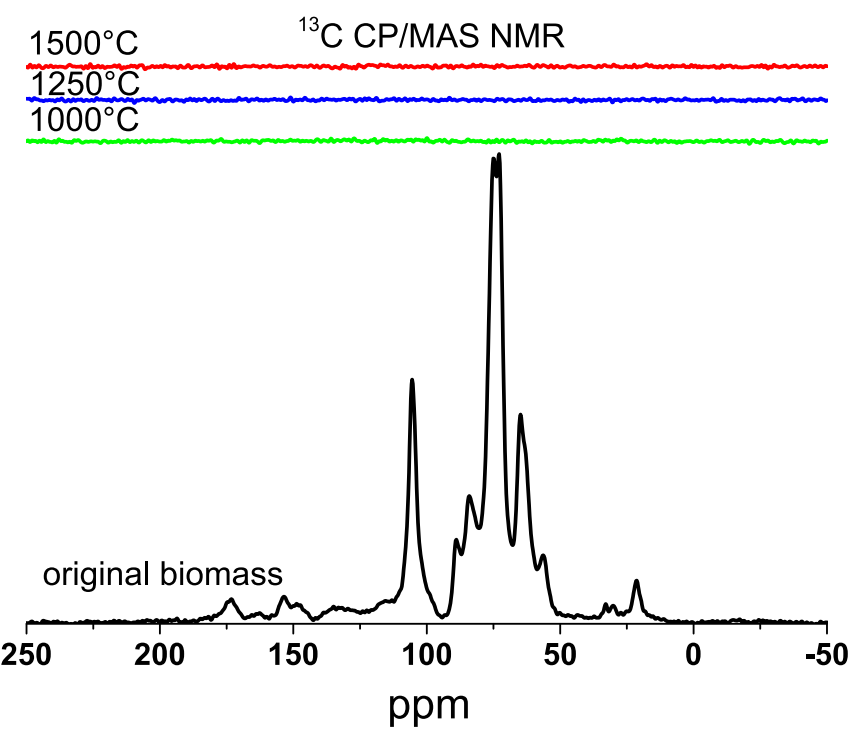

(a): Wheat straw ${ }^{13} \mathrm{C} \mathrm{CP} /$ MAS NMR

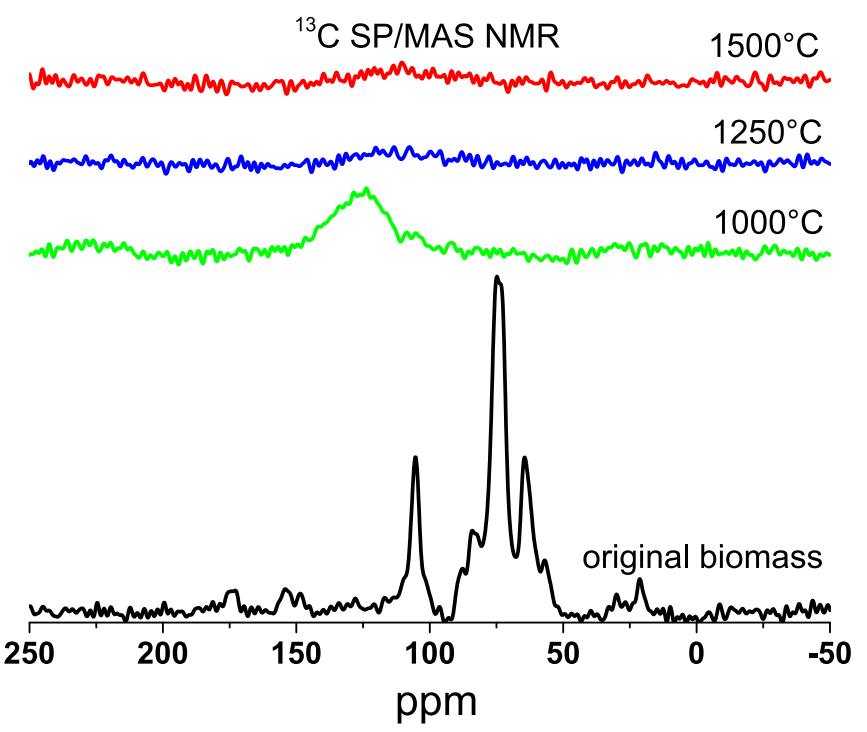

(b): Wheat straw ${ }^{13} \mathrm{C} \mathrm{SP} / \mathrm{MAS}$ NMR

Fig. 5. ${ }^{13} \mathrm{C} \mathrm{CP} / \mathrm{MAS}$ and ${ }^{13} \mathrm{C} \mathrm{SP} / \mathrm{MAS}$ spectra of wheat straw and its chars generated at 1000,1250 and $1500{ }^{\circ} \mathrm{C}$.

center of the full width at half maximum was selected according to constraints of Bertermann et al. [51]. The same type of data fitting was used to analyze the ${ }^{29} \mathrm{Si}$ SP/MAS NMR spectra. The results of fitting with Gaussian function indicated that the silicon oxides were mainly present in the rice husk chars in the amorphous form due to the width of the resonances originating from the $Q^{4}$ sites, which is in line with earlier studies on rice husk ashes of Hamdan et al. [18] and Lippmaa et al. [52]. They assigned the dominating relative area of $\mathrm{Q}^{4}$ site of rice husk ash to an "ill-ordered" amorphous silicates structure found in highly dispersed form. It seemed that no significant changes appeared in the ${ }^{29} \mathrm{Si}$ NMR spectra and thereby in the rice husk silicate structure at fast heating conditions. The increasing heat treatment temperature caused the relative amount of $Q^{3}$ species of original rice husk to decrease and $Q^{4}$ sites of original rice husk to increase, leading to a denser network with less surface sites and smaller reactivity towards oxygen [17]. The site oxygen reactivity in the silicon network follows the trend $Q^{1}>Q^{2}>Q^{3}>Q^{4}$ 


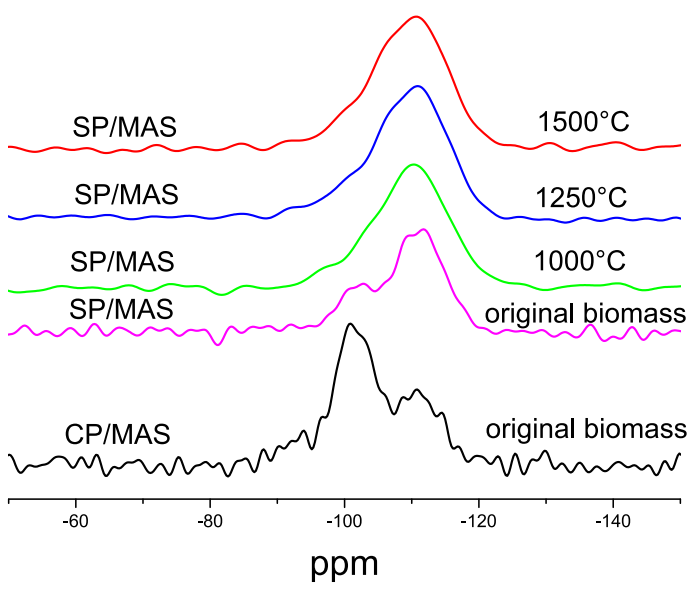

(a): ${ }^{29} \mathrm{Si} \mathrm{CP} / \mathrm{MAS}$ and SP/MAS NMR

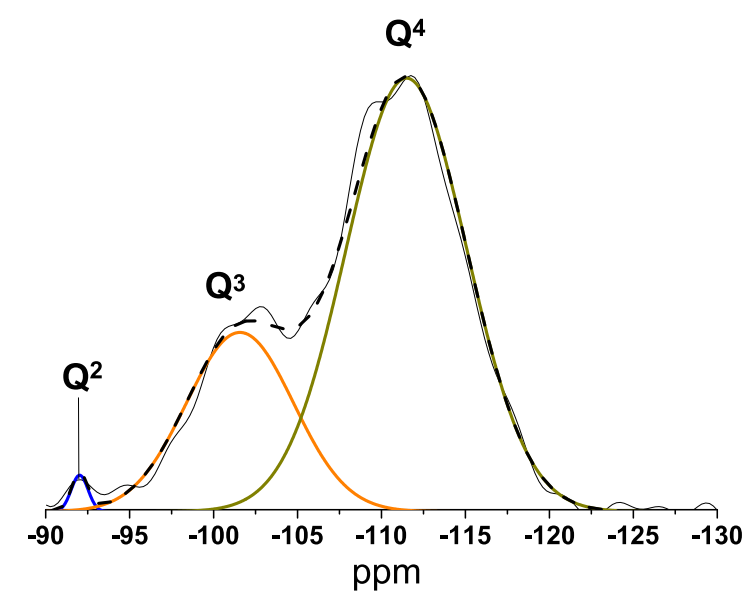

(b): SP/MAS spectrum fitting with Gaussian function for original rice husk

Fig. 6. (a) ${ }^{29} \mathrm{Si} \mathrm{CP} / \mathrm{MAS}$ and $\mathrm{SP} / \mathrm{MAS}$ NMR spectra of original rice husk; ${ }^{29} \mathrm{Si}$ SP/MAS NMR spectra of rice husk chars at 1000,1250 and $1500{ }^{\circ} \mathrm{C}$, and (b) results of the ${ }^{29} \mathrm{Si} \mathrm{SP} /$ MAS NMR data fitting with Gaussian function for original rice husk. investigations of Nair et al. [17], except for RHA-12Q sample oxidized for $12 \mathrm{~h}$, was related to the differences in a rice husk preparation. In their study, the rice husk was oxidized at 500, 700 and $900{ }^{\circ} \mathrm{C}$ in a fixed bed furnace from $15 \mathrm{~min}$ to $24 \mathrm{~h}$, and the rice husk ash was collected immediately or after it was naturally cooled down inside the oven, whereas in the present study the rice husk char was immediately cooled down after fast pyrolysis in a temperature range of $1000-1500{ }^{\circ} \mathrm{C}$. The fast quenching of rice husk chars in the entrained flow reactor favored the formation of amorphous silicates which is similar to the structure of silica glasses prepared at cooling rates of $1 \mathrm{kK} \mathrm{s}^{-1}$ to $1 \mathrm{MK} \mathrm{s}^{-1}$ [53-56].

The presence of broad resonances and lack of narrow resonances in the ${ }^{29} \mathrm{Si}$ SP/MAS NMR spectra indicates a glassy/disordered structure of the silica glasses [57], in line with earlier studies on rice husk ashes [17]. A crystalline phase in the rice husk ashes was formed at $1100{ }^{\circ} \mathrm{C}$ after $12 \mathrm{~h}$ oxidation, which was characterized by two intense narrow peaks with a maximum at $-110 \mathrm{ppm}$ $(\mathrm{FWHH} \approx 79.5 \mathrm{~Hz})$ and $-112 \mathrm{ppm}(\mathrm{FWHH} \approx 278 \mathrm{~Hz})$ assigned to cristobalite and tridymite phases. In the present study, the line width of $\mathrm{Q}^{3}$ site was almost three times broader than the narrow peak of crystalline silicates reported by Nair et al. [17], and exhibited a resonance broadness which is similar to non-crystalline silica glasses (i.e. non-crystalline opals) [58]. The peak with a maximum at $-112 \mathrm{ppm}$, which characterizes the crystallization of cristobalite, was not detected for rice husk chars prepared in a temperature range of $1000-1500{ }^{\circ} \mathrm{C}$. Thus, no comparison of the peak with a maximum at $-112 \mathrm{ppm}$ reported by Nair et al. [17] was made in the present investigation. This shows that silica remained mainly amorphous at fast pyrolysis conditions with the low content of a crystalline phase. However, the comparison of $\mathrm{Q}^{4}$ sites indicated that the broadness of the peak at $-111 \mathrm{ppm}$ in the literature remains similar to the line width of $\mathrm{Q}^{4}$ site in the present study which is equal to $2186 \mathrm{~Hz}$ at $1000{ }^{\circ} \mathrm{C}$ and $2384 \mathrm{~Hz}$ at $1250{ }^{\circ} \mathrm{C}$ and $1500{ }^{\circ} \mathrm{C}$.

For the chars of wheat straw resonances in the ${ }^{13} \mathrm{C} \mathrm{CP} / \mathrm{MAS}$ spectra were only observed for the original biomass, whereas resonances were observed from both the original biomass and the char at $1000{ }^{\circ} \mathrm{C}$ in the ${ }^{13} \mathrm{C} \mathrm{SP} / \mathrm{MAS}$ spectra. The decreased experimental sensitivity was related to the presence of paramagnetics in the carbonaceous bulk as it was proposed by Bardet et al. [10]. Due

Table 2

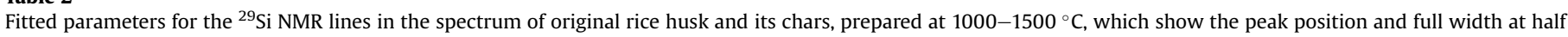
maximum, as it was proposed in the literature [9,20,67-69].

\begin{tabular}{|c|c|c|c|c|c|}
\hline \multirow[t]{2}{*}{ Silicon species } & \multirow[t]{2}{*}{ Mean iso. chem. shift (ppm) } & \multicolumn{4}{|c|}{ Full width at half maximum $(\mathrm{Hz})$} \\
\hline & & Raw sample & Char $\left(1000^{\circ} \mathrm{C}\right)$ & Char $\left(1250{ }^{\circ} \mathrm{C}\right)$ & Char $\left(1500^{\circ} \mathrm{C}\right)$ \\
\hline $\mathrm{Q}^{4},\left[\mathrm{Si}(\mathrm{OSi})_{4}\right]$ & -111 & 731 & 930 & 994 & 994 \\
\hline $\mathrm{Q}^{3},\left[(\mathrm{OH}) \cdot \mathrm{Si}(\mathrm{OSi})_{3}\right.$ & -102 & 604 & 874 & 962 & 963 \\
\hline $\mathrm{Q}^{2},\left[(\mathrm{OH})_{2} \cdot \mathrm{Si}(\mathrm{OSi})_{2}\right.$ & -92 & 96 & - & 217 & 219 \\
\hline
\end{tabular}

[19]. In $Q^{2}$ and $Q^{3}$ sites, the presence of non-bridging oxygen atoms made these silicon species more reactive than $Q^{4}$ sites due to the easier rearrangement of silicon network in chars. The $\mathrm{Q}^{2}$ and $\mathrm{Q}^{3}$ sites, due to the peak broadening, indicated an increase in the width from $96 \mathrm{~Hz}$ to $219 \mathrm{~Hz}$ and from $604 \mathrm{~Hz}$ to $963 \mathrm{~Hz}$ at $1500^{\circ} \mathrm{C}$ as shown in Table 2. The relative areas of $Q^{2}, Q^{3}$ and $Q^{4}$ sites of chars obtained at 1000,1250 and $1500^{\circ} \mathrm{C}$ remain nearly similar as shown in Table 3.

The results indicated that the original rice husk and their chars are composed mainly of $\mathrm{Q}^{4}$ sites $(72-80 \%)$ and to a minor extent of $\mathrm{Q}^{3}$ sites $(21-27 \%)$ along with small amounts $(<1.2 \%)$ of $\mathrm{Q}^{2}$ sites. In the present study, a lower relative area of $Q^{4}$ sites than in to the lower content of $\mathrm{Si}$, no resonances were observed in the ${ }^{29} \mathrm{Si}$ MAS NMR spectra of the wheat straw samples as shown in Fig. 5.

\subsection{Char characterization}

The particle size and shape of the original rice husk and wheat straw and chars prepared at $1000-1500{ }^{\circ} \mathrm{C}$ were analyzed with a 2D dynamic imaging device (CAMSIZER XT, Retsch) and SEM microscopy. The SEM microscopy results showed that rice husk chars contained large cavities inside the particle as shown in Fig. 8(a), whereas the outer part of the char exhibited a glassy shell consisting of rigid silica beads as shown in Fig. 8(b). A similar ash 


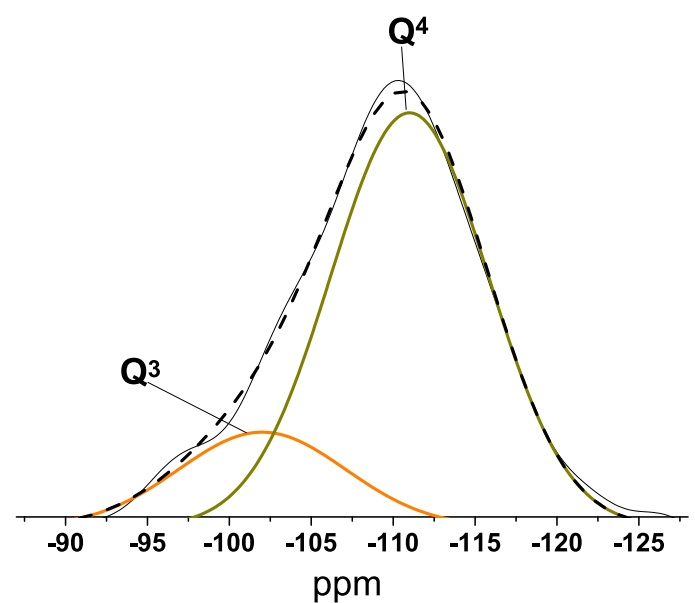

(a): SP/MAS spectra fitting with Gaussian function for rice husk char prepared at $1000^{\circ} \mathrm{C}$

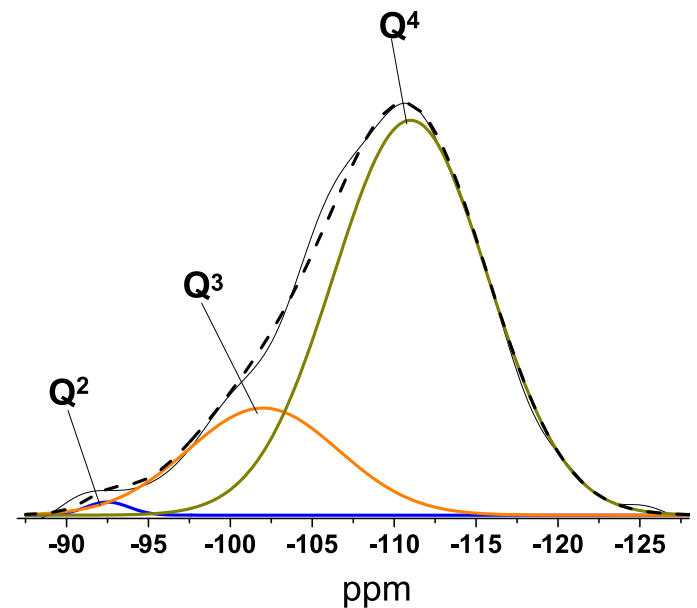

(b): SP/MAS spectrum fitting with Gaussian function for rice husk char prepared at $1500^{\circ} \mathrm{C}$

Fig. 7. Results of the ${ }^{29} \mathrm{Si} \mathrm{SP} / \mathrm{MAS}$ NMR data fitting with Gaussian function for chars prepared at (a) $1000{ }^{\circ} \mathrm{C}$ and (b) $1500{ }^{\circ} \mathrm{C}$.

Table 3

Calculated relative amounts of $\mathrm{Q}^{2}, \mathrm{Q}^{3}$ and $\mathrm{Q}^{4}(\%)$ based on the Gaussian fitting of ${ }^{29} \mathrm{Si}$ SP/MAS NMR spectra.

\begin{tabular}{llll}
\hline Temperature & $\mathrm{Q}^{2}(\%)$ & $\mathrm{Q}^{3}(\%)$ & $\mathrm{Q}^{4}(\%)$ \\
\hline Raw biomass & 0.9 & 26.6 & 72.5 \\
$1000{ }^{\circ} \mathrm{C}$ & - & 19.5 & 80.5 \\
$1250{ }^{\circ} \mathrm{C}$ & 1.1 & 22.9 & 76 \\
$1500{ }^{\circ} \mathrm{C}$ & 0.7 & 20.9 & 78.4 \\
\hline
\end{tabular}

morphology with a smooth outer surface and a large number of small grains was observed after oxidation of rice husk at $700{ }^{\circ} \mathrm{C}$ for $3 \mathrm{~h}$ by Krishnarao et al. [8]. They obtained only amorphous silicates and residual carbon in the white rice husk ash based on the XRD pattern. Overall, in the rice husk chars mainly amorphous silica and polyaromatic structures were detected in the present study. The XRD peak at about $23^{\circ}$ in the rice husk chars indicated formation of a turbostratic structure [42-44]. In addition, EDS analysis confirmed that the rice husk chars contained mainly carbon and silicon as described in Supplementary Table S-4.

The amorphous silicates dispersed throughout the organic matrix caused heterogeneous softening of rice husk char at high pyrolysis temperatures due to the molecular disorder of the structure as shown in Fig. 8(a). The shape of the rice husk chars remained preserved even at a higher temperature, due to the low softening temperature of amorphous silicon oxides $\left(\approx 730^{\circ} \mathrm{C}\right)$ [53] and rapid cooling of chars. The wheat straw chars obtained different shapes from near-spherical to cylindrical as shown in Fig. 8(c)-(d). However, the wheat straw char particles were mainly cylindrically-shaped as shown in Fig. 8(e).

Fig. 9 shows the particle frequency distribution based on volume ( $\left.\mathrm{q}_{3}\right)$ as a function of the characteristic length $\left(\mathrm{x}_{\mathrm{Ma}, \mathrm{min}}\right)$ of the original rice husk and wheat straw and their chars. The rice husk char kept the particle size of the original lignocellulosic material in a temperature range of $1000-1500{ }^{\circ} \mathrm{C}$. The particle size of wheat straw chars, however, was significantly reduced compared to the raw lignocellulosic material. The difference between the two biomass materials was due to the lower content of silicates in the wheat straw.

Regarding the shape, the main difference between the two herbaceous chars was that the rice husk char formed particles of a rectangular shape $(\mathrm{SPHT} \approx 0.8$ ) while the wheat straw char particles were mainly cylindrically-shaped and to a minor extent nearspherical (SPHT $\approx 0.5-0.8$ ) as shown in Fig. 9. The formation of near-spherical wheat straw chars containing cavities was affected by the presence of low-temperature melting potassium silicates. The cylindrically-shaped wheat straw particle formed a smooth surface without any pores, keeping the char structure similar to the original wheat straw particle due to the formation of hightemperature melting calcium silicates. The morphological differences between wheat straw char particles were related to the inorganic compounds allocation in the wheat straw as it was observed by Knudsen [41]. Pseudostem has a very high calcium content [59], whereas the wheat straw leaves contain high amounts of silicon and potassium [61,60]. Furthermore, the distribution of plant cell constituents in the biomass was also proposed to affect the formation of near-spherical char particles. The biomass char particles undergo softening and melting under fast heating [4]. At higher temperatures, the char plasticization occurs due to the formation of liquid metaplast. Depolymerization with subsequent repolymerization and cross-linking lead to char formation [62]. The differences in cross-linking propensity influence the fluidity of char significantly. The formation of metaplast depends on the complex interaction of all plant cell compounds (holocelluloses, lignin and extractives). Hansen et al. [63] reported that the stems of wheat straw contain more lignin and xylan compared to leaves. Trubetskaya et al. [64] suggested that at fast heating rates the formation of metaplast is mostly affected by the bond-breaking and cross-linking of organic components present in lignin that are less volatile than holocelluloses.

In the present study, the extent of plasticization of the char particles derived from wheat straw leaves was greater than that of char particles derived from straw stems. In addition, the $\mathrm{b}^{-1}$ ratio of rice husk and wheat straw chars decreased from 0.8 to 0.6 with decreasing particle size, indicating that both char particles exhibited a more elongated shape. Surprisingly, in the char collection bin of the BabiTER reactor, spherical particles, devoid of large cavities or pores and coated in soot were found. These particles varied in size from 1 to $15 \mu \mathrm{m}$, as shown in Fig. 8. However, the formation and chemistry of these particles has not been extensively discussed in the literature before. Posfai et al. [65] investigated the formation of tar balls, which are in size from 30 to $500 \mathrm{~nm}$ and consist of the low-volatile organic compounds, released during biomass burning. The tar balls are different from soot particles due to the lack of a graphitic nano-structure. Furthermore, the tar ball consists of about $90 \%$ carbon that makes them distinct from other carbonaceous 


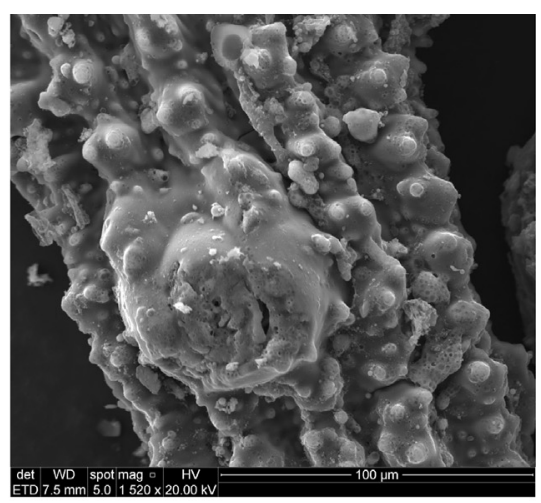

(a): Outer surface of rice husk char at $1500^{\circ} \mathrm{C}$

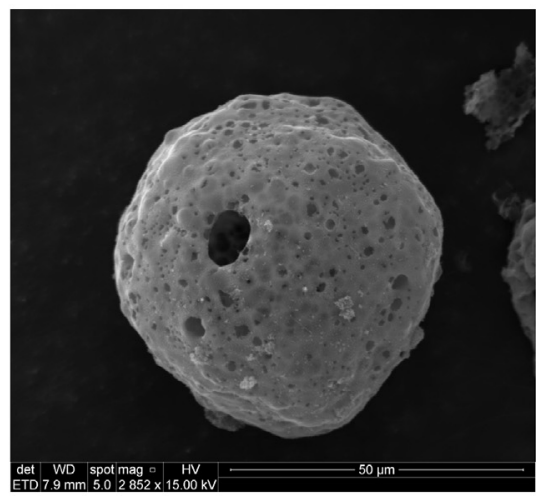

(c): Wheat straw char at $1250^{\circ} \mathrm{C}$

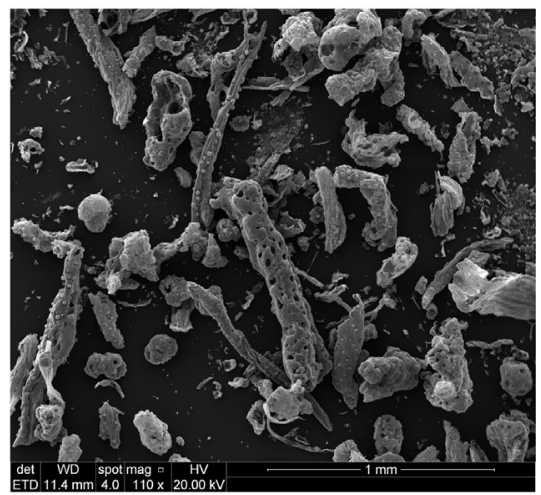

(e): Wheat straw char at $1250^{\circ} \mathrm{C}$

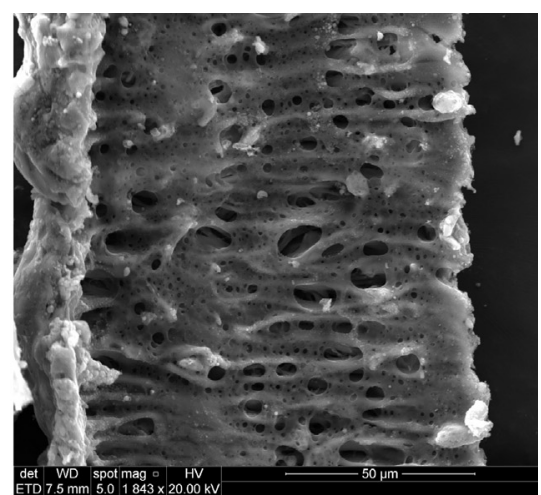

(b): Inner surface of rice husk char at $1500^{\circ} \mathrm{C}$

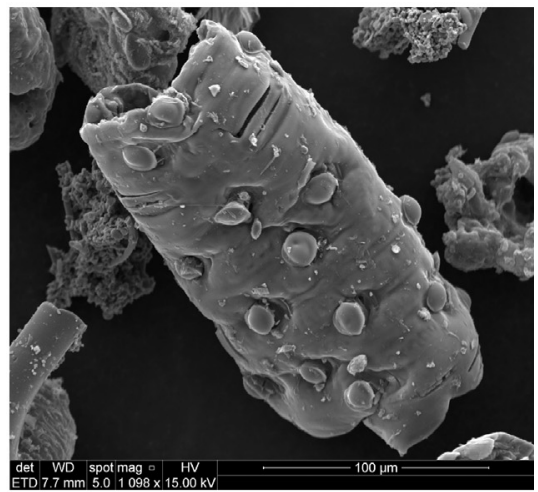

(d): Wheat straw char at $1250^{\circ} \mathrm{C}$

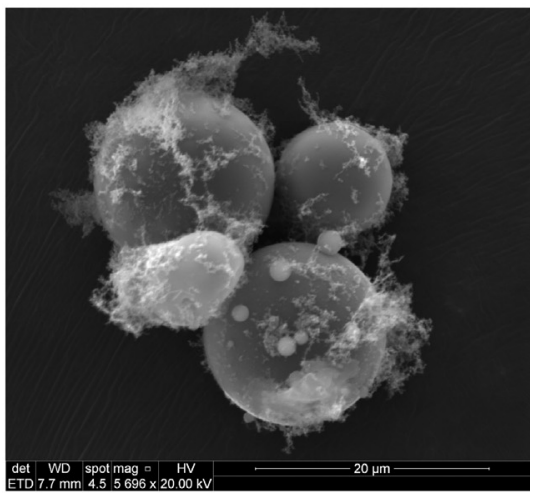

(f): Wheat straw tar ball at $1500^{\circ} \mathrm{C}$

Fig. 8. SEM images of wheat straw char prepared at $1250{ }^{\circ} \mathrm{C}$, rice husk char prepared at $1500{ }^{\circ} \mathrm{C}$ and tar balls from wheat straw pyrolysis at $1500{ }^{\circ} \mathrm{C}$ in the BabiTER reactor.

particles. In the present study, the chemical composition of particles with a smooth surface was not identified due to the low content of these particles found in the char bin. SEM/EDS analysis was conducted to analyze the composition of tar balls generated at $1500{ }^{\circ} \mathrm{C}$ and shown in Supplementary Table S-5. The results show that wheat straw tar balls contained predominantly $\mathrm{O}, \mathrm{Si}$, and $\mathrm{Ca}$ elements. However, it was hypothesized that the particles in Fig. 8(f) were formed from the low-volatility organic compounds, similarly to investigations of Posfai et al. [65].

\subsection{Surface area analysis}

The specific surface areas (SSA) of wheat straw and rice husk chars, measured by the $\mathrm{N}_{2}$-adsorption, are shown in Table 4 .
It can be observed that the rice husk chars had a lower surface area than the wheat straw at the same operational conditions. The surface area of wheat straw and rice husk chars was recalculated as surface area on dry ash free basis (daf) using Equation (4) as shown in Table 4.

$S S A_{d a f}=\frac{S S A}{1-A-M}$

In Equation 4, $\mathrm{A}$ and $\mathrm{M}$ are fractions of ash and moisture. Since the ash has a lower surface area compared to char, and rice husk has a higher ash content compared to wheat straw, the surface area of rice husk became smaller. However, the surface area on ash free basis of wheat straw and rice husk was similar for chars prepared at 1250 and $1500^{\circ} \mathrm{C}$, indicating no significant changes with increasing 


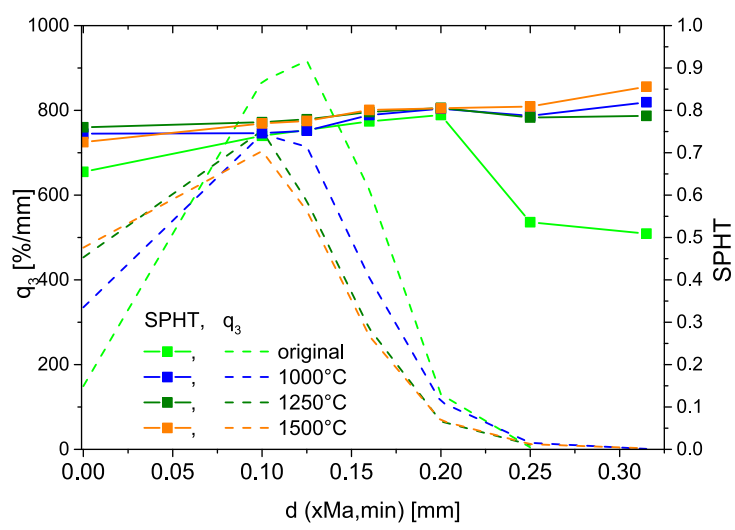

(a): $\mathrm{q}_{3}$ and SPHT (rice husk)

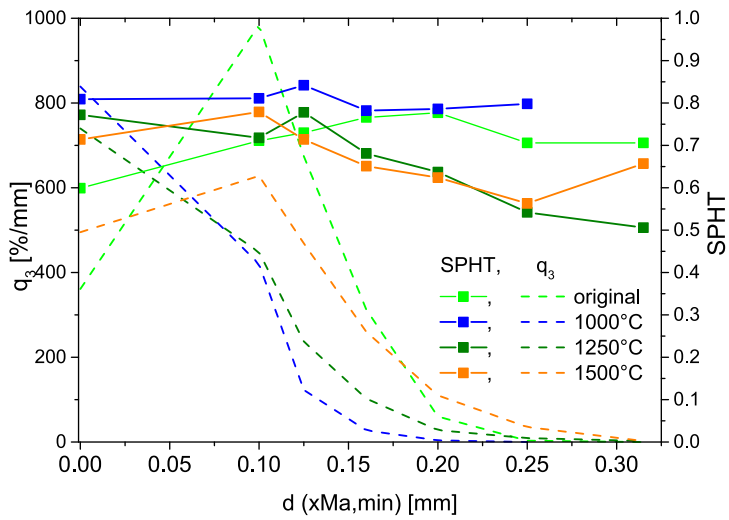

(c): $\mathrm{q}_{3}$ and SPHT (wheat straw)

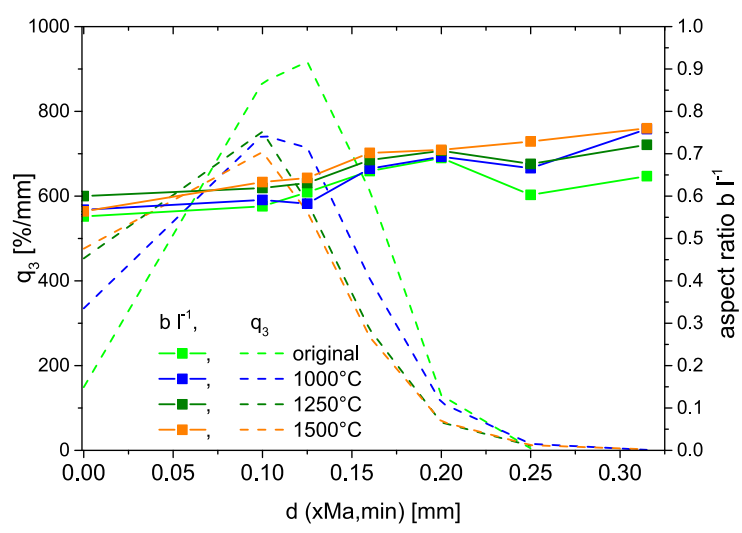

(b): $\mathrm{q}_{3}$ and $\mathrm{b} \mathrm{l}^{-1}$ (rice husk)

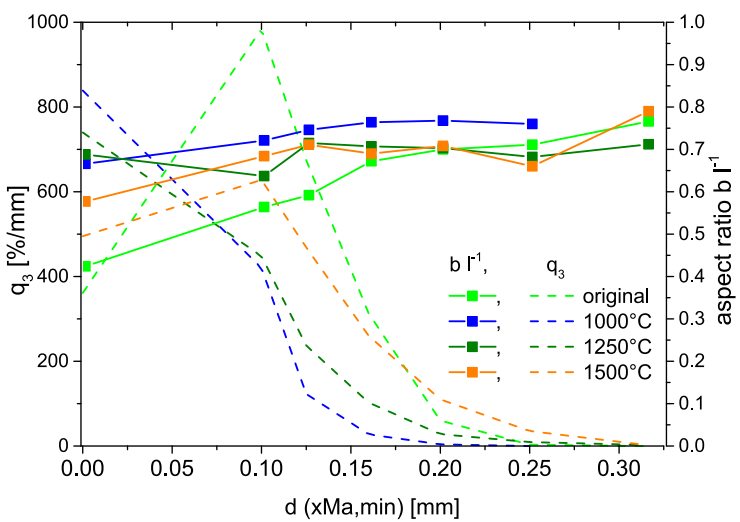

(d): $\mathrm{q}_{3}$ and $\mathrm{b}^{-1}$ (wheat straw)

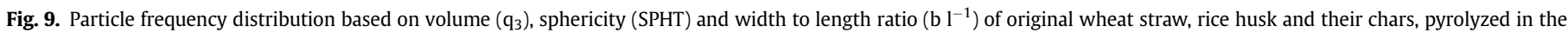

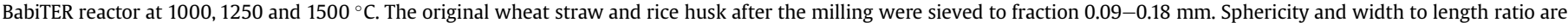
shown as straight lines and $\mathrm{q}_{3}$ is shown with a dashed line.

Table 4

Surface area by $\mathrm{N}_{2}$-adsorption of wheat straw and rice husk chars, prepared at $1250-1500{ }^{\circ} \mathrm{C}$. Due to the volatile matter presence in the wheat straw and rice husk chars generated at $1000{ }^{\circ} \mathrm{C}$, the $\mathrm{N}_{2}$-adsorption was not conducted.

\begin{tabular}{|c|c|c|c|c|}
\hline Temperature & Rice husk & Wheat straw & Rice husk & Wheat straw \\
\hline${ }^{\circ} \mathrm{C}$ & \multicolumn{2}{|c|}{$\mathrm{m}^{2} \mathrm{~g}^{-1}$, as received } & \multicolumn{2}{|c|}{$\overline{\mathrm{m}^{2} \mathrm{~g}^{-1} \text {, on dry ash free basis }}$} \\
\hline 1250 & 94.9 & 197 & 527 & 318 \\
\hline 1500 & 53.3 & 167 & 533 & 336 \\
\hline
\end{tabular}

temperature.

\subsection{Reactivity and burnout}

The reactivity of rice husk and wheat straw chars towards oxygen was investigated in a TG instrument to understand the effect of heat treatment temperature and lignocellulosic material type. The wheat straw and rice husk chars, prepared at 1000, 1250 and $1500{ }^{\circ} \mathrm{C}$, were oxidized with a heating rate of $10 \mathrm{~K} \mathrm{~min}^{-1}$ up to $1350{ }^{\circ} \mathrm{C}$. The derivatives of the mass loss signals of the char in $5 \%$ volume fraction $\mathrm{O}_{2}$ are shown as a function of temperature in Fig. 10.

The maximum conversion rate of the wheat straw chars took place between 400 and $550{ }^{\circ} \mathrm{C}$, whereas the maximum conversion rate of rice husk chars was shifted to approximately $100{ }^{\circ} \mathrm{C}$ higher temperatures. This shows that the wheat straw chars were

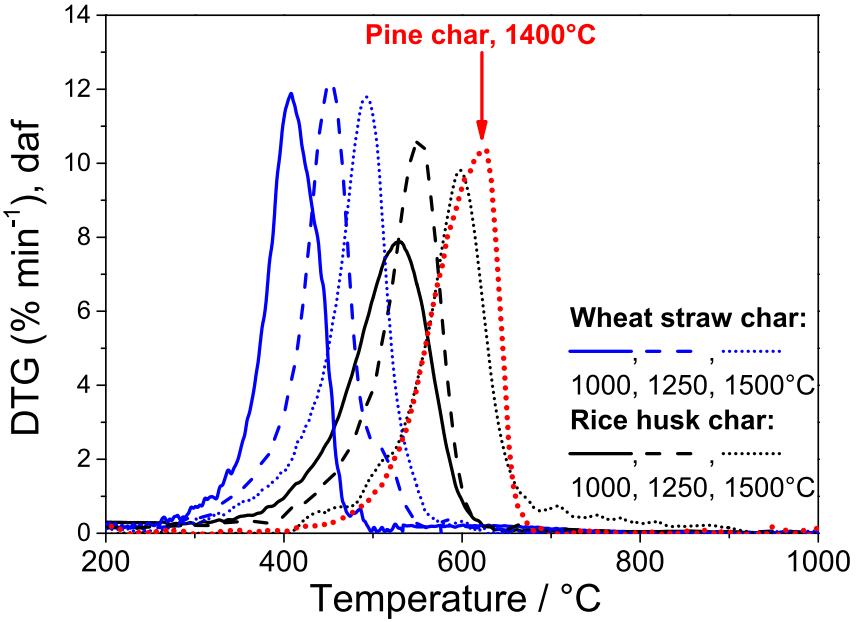

Fig. 10. Differential thermogravimetric analysis (DTG curves) of rice husk and wheat straw chars as a function of heat treatment temperature, pyrolyzed in BabiTER reactor at 1000,1250 and $1500{ }^{\circ} \mathrm{C}$, and compared with the reactivity of pinewood char generated in the drop tube reactor at $1400{ }^{\circ} \mathrm{C}$ [66].

significantly more reactive than the rice husk chars. The main reason for the difference in reactivity was the higher level of alkali metals in the wheat straw chars compared to rice husk, which 
catalyzes the oxidation reaction. The Arrhenius parameters for char oxidation derived from the TG experiments are shown in Supplementary Table S-6. At an average temperature of $400^{\circ} \mathrm{C}$, the rate constant for wheat straw char oxidation decreased from $2 \cdot 10^{-3}$ to $5 \cdot 10^{-4} \mathrm{~s}^{-1}$ as the heat treatment temperature increased from 1000 to $1500{ }^{\circ} \mathrm{C}$. For rice husk, the rate constant decreased correspondingly from $3 \cdot 10^{-4}$ to $1 \cdot 10^{-5} \mathrm{~s}^{-1}$. The reactivities of rice husk chars were compared with that of pinewood char generated in the drop tube reactor at $1400{ }^{\circ} \mathrm{C}$ as reported by Trubetskaya et al. [66]. The reactivities of pinewood and rice husk chars were similar, indicating less influence of silicon oxides on the char reactivity. Furthermore, both chars were deactivated at high heat treatment temperatures due to thermal annealing forming more ordered polyaromatic structures with graphene-like layers, leading to char deactivation, in agreement with the results of Pottmaier et al. [11].

\section{Conclusion}

By ${ }^{29}$ Si MAS NMR of both original rice husk and their chars broad resonances similar to what was observed in silica glasses were obtained. This demonstrates that the major part of the silicates were present in a disordered/amorphous state. No significant changes appeared in the ${ }^{29} \mathrm{Si}$ NMR spectra for $\mathrm{Q}^{2}, \mathrm{Q}^{3}$ and $\mathrm{Q}^{4}$ branches of rice husk chars, meaning almost negligible differences in the char $\mathrm{Si}$ bearing compounds in a temperature range of $1000-1500{ }^{\circ} \mathrm{C}$ in fast pyrolysis. The resonances in ${ }^{29} \mathrm{Si} \mathrm{CP} / \mathrm{MAS}$ NMR spectra of original wheat straw and its chars were not observed due to the low amount of silicates, high content of paramagnetics or an increased electrical conductivity of chars in fast pyrolysis. However, equilibrium calculations using Factsage software indicated that wheat straw chars contain potassium and calcium silicates.

The presence of silicates in the rice husk and wheat straw was proposed to affect the obtained char morphology. The particle shape of rice husk remained preserved at high heat treatment temperatures as observed by the 2D dynamic imaging analysis and SEM microscopy. The lower silicates content and high levels of alkali in the wheat straw caused variations in char particle shapes from cylindrical to near-spherical. The lack of long-range order in XRD analysis and the broad resonances in ${ }^{29} \mathrm{Si}$ solid-state NMR confirmed that silicates in rice husk chars were present in a glassamorphous form, leading to the formation of a glassy char shell due to the softening of the amorphous silicon oxides. The results of the present study indicated a key role of Si bearing compounds on the char mechanical integrity.

The wheat straw chars were observed to be more reactive than the rice husk chars due to the higher level of alkali metals which catalyzes the oxidation of carbon as can be seen by the thermogravimetric analysis. Similar reactivities of rice husk and pinewood showed that silicon oxides affect less the char reactivity than the alkali metals. Moreover, the reactivity of both wheat straw and rice husk chars decreased at high heat treatment temperatures due to annealing of the carbon. The BET surface area of wheat straw and rice husk chars had less influence on the char reactivity due to the negligible differences in the temperature range of $1250-1500{ }^{\circ} \mathrm{C}$.

\section{Acknowledgments}

The authors would like to acknowledge the financial support that they received for this project from Danish Strategic Research Council (Grant DSF-10-093956), DONG Energy and Vattenfall. We also thank Gert Beckmann (Retsch Company) for assisting with the reproducibility tests on CAMSIZER XT, Professor Kenny Ståhl (DTU Chemistry) and Sunday Chukwudi Okoro (DTU, Chemical Engineering) for support with the XRD measurements and data processing, Dr. Martin Høj (DTU, Chemical Engineering) for assisting with $\mathrm{N}_{2}$-adsorption analysis and Andrea Hartung (TU Munich) for the careful ash compositional analysis. We emphasize special thank you to Andreas Geißler, Simon Schatzmann and Benedikt Schels for their support during measurements on the entrained flow reactor.

\section{Appendix A. Supplementary data}

Supplementary data related to this article can be found at http:// dx.doi.org/10.1016/j.biombioe.2016.01.017.

\section{References}

[1] W. Lin, P.A. Jensen, A.D. Jensen, Biomass suspension combustion: effect of two-stage combustion on $\mathrm{NO}_{x}$ emissions in a laboratory-scale swirl burner, Energy Fuels 23 (3) (2009) 1398-1405.

[2] H. Wu, M.S. Bashir, P.A. Jensen, B. Sander, P. Glarborg, Impact of coal fly ash addition on ash transformation and deposition in a full-scale wood suspension-firing boiler, Fuel 113 (2013) 632-643.

[3] M.J. Wornat, R.H. Hurt, N.Y.C. Yang, T.J. Headley, Structural and compositional transformations of biomass chars during combustion, Combust. Flame 100 (1-2) (1995) 131-145.

[4] E. Cetin, B. Moghtaderi, R. Gupta, T.F. Wall, Influence of pyrolysis conditions on the structure and gasification reactivity of biomass chars, Fuel 83 (16) (2004) 2139-2150.

[5] M. Dall'Ora, P.A. Jensen, A.D. Jensen, Suspension combustion of wood: influence of pyrolysis conditions on char yield, morphology, and reactivity, Energy Fuels 22 (5) (2008) 2955-2962.

[6] C. Real, M.D. Alcala, J.M. Criado, Preparation of silica from rice husks, J. Am. Ceram. Soc. 79 (8) (1996) 2012-2016.

[7] J.R. Cassiday, D.R. Beaman, C.K. Black, A.W. Weimer, D.W. Susnitzky, Carbothermal nitridation synthesis of $\alpha-\mathrm{Si}_{3} \mathrm{~N}_{4}$ powder from pyrolysed rice hulls, J. Mater. Sci. 31 (1996) 6005-6013.

[8] R.V. Krishnarao, M.M. Godkhindi, Distribution of silica in rice husk and its effect on the formation of silicon carbide, Ceram. Int. 18 (4) (1992) 243-249.

[9] J.C.C. Freitas, F.G. Emmerich, T.J. Bonagamba, High-resolution solid-state NMR study of the occurrence and thermal transformations of silicon-containing species in biomass materials, Chem. Mater. 12 (3) (2000) 711-718.

[10] M. Bardet, S. Hediger, G. Gerbaud, S. Gambarelli, J.F. Jacquot, M.F. Foray, A. Gadelle, Investigation with ${ }^{13} \mathrm{C}$ NMR, EPR and magnetic susceptibility measurements of char residues obtained by pyrolysis of biomass, Fuel 86 (12-13) (2007) 1966-1976.

[11] D. Pottmaier, M. Costa, T. Farrow, A.A.M. Oliveira, O. Alarcon, C. Snape, Comparison of rice husk and wheat straw: from slow and fast pyrolysis to char combustion, Energy Fuels 27 (11) (2013) 7115-7125.

[12] F.C. Lanning, Silicon in rice, J. Agric. Food Chem. 11 (5) (1963) 435-437.

[13] S.L. Liu, C.H. Ho, Study in the nature of silicon in rice hull. I. Solubility of the silicon part, J. Chin. Chem. Soc. 6 (2) (1960) 141-153.

[14] R.K. Sharma, J.B. Wooten, V.L. Baliga, X. Lin, G. Chan, M.R. Hajaligol, Characterization of char from the pyrolysis of tobacco, J. Agric. Food Chem. 50 (4) (2002) 771-783.

[15] M. Guerrero, M. Pilar-Ruiz, A. Millera, M.U. Alzueta, R. Bilbao, Characterization of biomass chars formed under different devolatilization conditions: differences between rice husk and eucalyptus, Energy Fuels 22 (2) (2008) 1275-1284.

[16] M. Nehdi, J. Duquette, A.E. Damatty, Performance of rice husk ash produced using a new technology as a mineral admixture in concrete, Cem. Concr. Res. 33 (8) (2003) 1203-1210.

[17] D.G. Nair, A. Fraaij, A.A.K. Klaassen, A.P.M. Kentgens, A structural investigation relating to the pozzolanic activity of rice husk ashes, Cem. Concr. Res. 38 (6) (2008) 861-869.

[18] H. Hamdan, M.N.M. Muhid, S. Endud, E. Salasiah, E. Listiorini, Z. Ramli, ${ }^{29} \mathrm{Si}$ MAS NMR, XRD and FESEM studies of rice husk silica for the synthesis of zeolites, J. Non Cryst. Solids 211 (1) (1997) 126-131.

[19] B.C. Bunker, Molecular mechanisms for corrosion of silica and silicate glasses, J. Non Cryst. Solids 179 (1994) 300-308.

[20] R.F. Abreu, J. Schneider, M.A. Cincotto, Structure and hydration kinetics of silica particles in rice husk ash studied by ${ }^{29} \mathrm{Si}$ high-resolution nuclear magnetic resonance, J. Am. Ceram. Soc. 88 (6) (2005) 1514-1520.

[21] A.S. Politou, C. Morterra, M.J.D. Low, Infrared studies of carbons. XII the formation of chars from a polycarbonate, Carbon 28 (4) (1990) 529-538.

[22] A. Sluiter, B. Hames, R. Ruiz, C. Scarlata, J. Sluiter, D. Templeton, et al, Determination of Structural Carbohydrates and Lignin in Biomass, National Renewable Energy Laboratory, Golden (CO), 2011 July. Report No. NREL/TP510-42618. Contract No.: DE-AC36-08-G028308.

[23] S. Willför, J. Hemming, A.S. Leppänen, Analysis of Extractives in Different Pulps - Method Development, Evaluation, and Recommendations, Åbo Akademi University, Laboratory of Wood and Paper Chemistry, Finland, 20042009. Report No. B1 of the EU COST E41 action "Analytical tools with applications for wood and pulping chemistry".

[24] B. Hames, R. Ruiz, C. Scarlata, J. Sluiter, A. Sluiter, Preparation of Samples for Compositional Analysis, National Renewable Energy Laboratory, Golden (CO), 
2011 June. Report No. NREL/TP-510-42620. Contract No.: DE-AC36-99G010337.

[25] K. Thammasouk, D. Tandjo, M.H. Penner, Influence of extractives on the analysis of herbaceous biomass, J. Agric. Food Chem. 45 (2) (1997) 437-443.

[26] A. Tremel, T. Haselsteiner, C. Kunze, H. Spliethoff, Experimental investigation of high temperature and high pressure coal gasification, Appl. Energy 92 (2012) 279-285.

[27] A. Tremel, Reaction Kinetics of Solid Fuels during Entrained Flow Gasification (PhD thesis), Technical University of Munich, 2012.

[28] M. Stiess, Mechanische Verfahrenstechnik 1 (in German), Springer, 1992.

[29] H.G. Merkus, Particle Size Measurements, Springer, 2009.

[30] O.B. Peersen, X. Wu, I. Kustanovich, S.O. Smith, Variable-amplitude crosspolarization MAS NMR, J. Magn. Reson. Ser. A 104 (3) (1993) 334-339.

[31] A.E. Bennett, C.M. Rienstra, M. Auger, K.V. Lakshmi, R.G. Griffin, Heteronuclear decoupling in rotating solids, J. Chem. Phys. 103 (1995) 6951-6958.

[32] M.J. Potrzebowski, P. Tekely, Y. Dusausoy, Comment to ${ }^{13} \mathrm{C}$ NMR studies of alpha and gamma polymorphs of glycine, Solid State Nucl. Magn. Reson. 11 (3-4) (1998) 253-257.

[33] S. Brunauer, P.H. Emmett, E. Teller, Adsorption of gases in multimolecular layers, J. Am. Chem. Soc. 60 (2) (1938) 309-319.

[34] A.W. Coats, J.P. Redfern, Kinetic parameters from thermogravimetric data, Nature 201 (1964) 68-69.

[35] K. Qin, W. Lin, S. Foster, P.A. Jensen, H. Wu, A.D. Jensen, Characterization of residual particulates from biomass entrained flow gasification, Energy Fuels 27 (2013) 262-270.

[36] J.N. Knudsen, P.A. Jensen, K. Dam-Johansen, Transformation and release to the gas phase of $\mathrm{Cl}, \mathrm{K}$ and $\mathrm{S}$ during combustion of annual biomass, Energy Fuels 18 (5) (2004) 1385-1399.

[37] F.C. Kracek, N.L. Bowen, G.W. Morey, Equilibrium relations and factors influencing their determination in the system $\mathrm{K}_{2} \mathrm{SiO}_{3}-\mathrm{SiO}_{2}$, J. Phys. Chem. 41 (9) (1937) 1183-1193.

[38] G.E. Seil, Orthosilicates of the alkaline earths with special reference to their uses in the refractory field, J. Am. Ceram. Soc. 24 (1) (1941) 1-19.

[39] L. Jing, M. Yu-Zhao, L. Zhi-Wei, L. An-Xian, Preparation of transparent glassceramics with high crystallinity, Chin. J. Nonferr. Met. 21 (6) (2011) 1450-1456.

[40] M.K. Sharma, W.S. Williams, A. Zangvil, Formation and structure of silicon carbide whiskers from rice hulls, J. Am. Ceram. Soc. 67 (11) (1984) 715-720.

[41] J.N. Knudsen, Volatilization of Inorganic Matter during Combustion of Annual Biomass (PhD thesis), Technical University of Denmark, 2004.

[42] M. Keiluweit, R.S. Nico, M.G. Johnson, M. Kleber, Dynamic molecular structure of plant biomass-derived black carbon (biochar), Environ. Sci. Technol. 44 (4) (2010) 1247-1253.

[43] M. Poletto, V. Pistor, A.J. Zattera, Chapter 2. Structural characteristics and thermal properties of native cellulose, in: T. van de Ven, L. Godbout (Eds.) Cellulose - Fundamental Aspects, InTech, 2013.

[44] A. Kumar, Y.S. Negi, V. Choudhary, N.K. Bhardwaj, Characterization of cellulose nanocrystals produced by acid-hydrolysis from sugarcane bagasse as agrowaste, J. Mater. Phys. Chem. 2 (1) (2014) 1-8.

[45] E.A. Webster, J.A. Chudek, D.W. Hopkins, Carbon transformations during decomposition of different components of plant leaves in soil, Soil Biol. Biochem. 32 (3) (2000) 301-314.

[46] M. Bardet, S. Maron, M.F. Foray, M. Berger, A. Guillermo, Investigation of gamma-irradiated vegetable seeds with high-resolution solid-state ${ }^{13} \mathrm{C}$ NMR Radiat. Res. 161 (4) (2004) 458-463.

[47] F. Xu, J.X. Sun, R.C. Sun, P. Fowler, M. Baird, Comparative study of organosolv lignins from wheat straw, Ind. Crops Prod. 23 (2) (2006) 180-193.

[48] M. Bardet, G. Gerbaud, M. Giffard, C. Doan, S. Hediger, L.L. Pape, ${ }^{13} \mathrm{C}$ highresolution solid-state NMR for structural elucidation of archaeological woods, Prog. Nucl. Magn. Reson. Spectrosc. 55 (3) (2009) 199-214.
[49] D.G. Reid, S.L. Bonnet, G. Kemp, J.H. van der Westhuizen, Analysis of commercial proanthocyanidins. Part 4: solid state ${ }^{13} \mathrm{C}$ NMR as a tool for in situ analysis of proanthocyanidin tannins, in heartwood and bark of quebracho and acacia, and related species, Photochem 94 (2013) 243-248.

[50] E. Lippmaa, M. Maegi, A. Samoson, G. Engelhardt, A.R. Grimmer, Structura] studies of silicates by solid-state high-resolution silicon-29 NMR, J. Am. Chem. Soc. 102 (15) (1980) 4889-4893.

[51] R. Bertermann, R. Tacke, Solid-state ${ }^{29}$ Si VACP/MAS NMR studies of siliconaccumulating plants: structural characterization of biosilica deposits, Z. Naturforsch. 55b (2000) 459-461.

[52] E.T. Lippmaa, A.V. Samoson, V.V. Brei, I.I. Gorlov, Investigation of the surfacestructure of high-dispersed silica by the methods of high-resolution Si-29 and H-1-NMR in solid state, Dokl. Akad. Nauk. SSSR 259 (2) (1981) 403-408.

[53] A. Hedler, S.L. Klaumünzer, W. Wesch, Amorphous silicon exhibits a glass transition, Nat. Mater. 3 (2004) 804-809.

[54] S. Webb, Silicate melts: relaxation, rheology, and the glass transition, Rev. Geophys. 35 (2) (1997) 191-218.

[55] P.G. Debenedetti, F.H. Stillinger, Supercooled liquids and the glass transition, Nature 410 (6825) (2001) 259-267.

[56] D.P. Birnie, M.D. Dyar, Cooling rate calculations for silicate glasses, Proc 16th Lunar and Planetary Sci. Conf., Part 2, J. Geophys. Res. 91 (B4) (1986) D509-D513.

[57] J.F. Stebbins, Identification of multiple structural species in silicate glasses by ${ }^{29}$ Si NMR, Nature 330 (6147) (1987) 465-467.

[58] H. Graetsch, A. Mosset, H. Gies, XRD and ${ }^{29}$ Si MAS-NMR study on some noncrystalline silica minerals, J. Non Cryst. Solids 119 (2) (1990) 173-180.

[59] A. Nurfeta, A. Tolera, L.O. Eik, F. Sundstøl, Feeding value of enset (Ensete ventricosum), Desmodium intortum hay and untreated or urea and calcium oxide treated wheat straw for sheep, J. Anim. Physiol. Anim. Nutr. 93 (1) (2008) 94-104.

[60] C. Atik, S. Ates, Mass balance of silica in straw from the perspective of silica reduction in straw pulp, Bioresources 7 (3) (2012) 3274-3282.

[61] S. Ikeda, Y. Yamashita, I. Kreft, Mineral composition of buckwheat by-products and its processing characteristics to konjak preparation, Fagopyrum 16 (1999) 89-94.

[62] P.R. Solomon, M.A. Serio, E.M. Suuberg, Coal pyrolysis: experiments, kinetic rates and mechanisms, Prog. Energy Combust. Sci. 18 (2) (1992) 133-220.

[63] M.A.T. Hansen, B.J. Hidayat, K.K. Mogensen, M.D. Jeppesen, B. Jørgensen, K.S. Johansen, et al., Enzyme affinity to cell types in wheat straw (Triticum aestivum L.) before and after hydrothermal pretreatment, Biotech. Biofuels 6 (1) (2013) 1-15.

[64] A. Trubetskaya, P.A. Jensen, J.D. Jensen, M. Steibel, H. Spliethoff, P. Glarborg, Influence of fast pyrolysis conditions on yield and structural transformation of biomass chars, Fuel Process Tech. 140 (2015) 205-214.

[65] M. Posfai, A. Gelencser, R. Simonics, K. Arato, J. Li, P.V. Hobbs, et al., Atmospheric tar balls: particles from biomass and biofuel burning, J. Geophys. Res. 109 (D6) (2004) 1-9.

[66] A. Trubetskaya, P.A. Jensen, J.D. Jensen, A.D. Llamas Garcia, K. Umeki, P. Glarborg, Effect of fast pyrolysis conditions on biomass solid residues at high temperatures, Fuel Process Tech. 143 (2016) 118-129.

[67] D. Prasetyoko, Z. Ramli, S. Endud, H. Hamdan, B. Sulikowski, Conversion of rice husk ash to zeolite beta, Waste Manag. 26 (10) (2006) 1173-1179.

[68] J. Davidovits, Application of Ca-based geopolymer with blast furnace slag, a review, in: 2nd International Slag Valorisation Symposium, 2011, pp. 33-49.

[69] A. Palomo, P. Krivenko, I. Garcia-Lodeiro, E. Kavalerova, O. Maltseva, A. Fernandez-Jimenez, A review on alkaline activation: new analytical perspectives, Mater. Constr. 64 (315) (2014) 1-24.

[70] L. Etiegni, A.G. Campbell, Physical and chemical characteristics of wood ash, Bioresour. Technol. 37 (2) (1991) 173-178. 